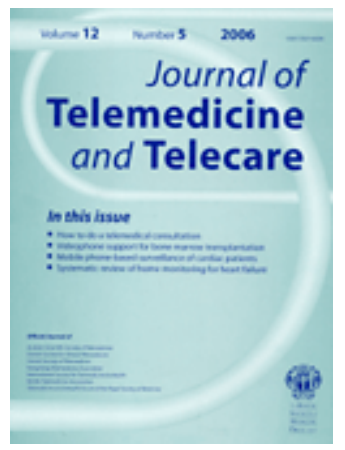

\title{
Components, design, and effectiveness of digital physical rehabilitation interventions for older people: a systematic review.
}

\begin{tabular}{|r|l|}
\hline Journal: & Journal of Telemedicine and Telecare \\
\hline Manuscript ID & JTT-20-03-036.R1 \\
\hline Manuscript Type: & Research \\
\hline Date Submitted by the & n/a \\
\hline Complete List of Authors: & $\begin{array}{l}\text { TONGA, EDA; Marmara University, Physiotherapy and Rehabilitation } \\
\text { Srikesavan, Cynthia; University of Oxford, Nuffield Department of } \\
\text { Orthopaedics and Musculoskeletal Sciences; University of Oxford } \\
\text { Williamson, Esther; University of Oxford, Nuffield Department of } \\
\text { Orthopaedics and Musculoskeletal Sciences } \\
\text { Lamb, Sarah; University of Oxford, Centre for Rehabilitation Research in } \\
\text { Oxford, University of Oxford, UK }\end{array}$ \\
\hline Keyword: & older adults, digital rehabilitation, ehealth, mhealth \\
\hline &
\end{tabular}

\section{SCHOLARONE Manuscripts}




\section{Manuscript Title}

Components, design, and effectiveness of digital physical rehabilitation interventions for older people: a systematic review.

\section{Running head}

Digital rehabilitation interventions for older adults

\section{Article category}

Systematic review

\section{Eda Tonga ${ }^{1}$, Cynthia Srikesavan², Esther Williamson ${ }^{2}$, Sarah E Lamb ${ }^{2,3}$}

${ }^{1}$ Marmara University, Faculty of Health Sciences, Department of Physiotherapy, Istanbul, Turkey

${ }^{2}$ Centre for Rehabilitation Research in Oxford, University of Oxford, UK

${ }^{3}$ University of Exeter, Collage of Medicine and Health, Exeter, UK

Correspondence information: Eda Tonga, Marmara University Faculty of Health Science, Department of Physiotherapy and Rehabilitation, MÜ. Başıbüyük Campus, Başıbüyük St. 3484, Maltepe, Istanbul, Turkey.

Email: eda.tonga@gmail.com

\section{Declaration of interest}

The authors report no declarations of interest.

\section{Acknowledgements}

We would like to thank Eli Harriss who is the knowledge centre manager at Bodleian Health care Libraries for contributions to search strategy. We would like to thank you to Dr. Bethan Copsey to double checking the metanalysis applicability.

This research was supported by the SE2020 Translational Fund for Social Impact at the University of Oxford and the National Institute for Health Research (NIHR) Collaboration for Leadership in Applied Health Research and Care Oxford at Oxford Health NHS Foundation Trust.

\section{Systematic review protocol registration}

Name of the registry: PROSPERO International Prospective Register of Systematic Reviews

Date of registration: 13 November 2018

Registration number: CRD42018042471

URL: https://www.crd.york.ac.uk/PROSPERO/display_record.php?RecordID=42471. 


\section{Components, design, and effectiveness of digital physical rehabilitation interventions for older people: a systematic review.}

\section{Summary}

Background: With the rapid advancement in digital technologies, the use of digital health applications is increasing day by day. Although a large number of digital applications have been developed for rehabilitation of older people, there has been no review of the evidence for effectiveness of these interventions. Methods: The aim of our study was to review the evidence of digital rehabilitation interventions on outcomes including pain, function and quality of life in older people. We focus on digital interventions that are designed to improve and restore physical functioning. We searched six electronic bibliographic databases and included randomized controlled trials. Cochrane risk of bias tool and Cochrane's GRADE's_approach were used to evaluate the risk of bias and grad the evidence. Results: Eight trials were included. The short-term effects of digital rehabilitation interventions on physical activity, quality of life, vertigo symptoms and falls are uncertain. Quality of trials were rated as very low to moderate evidence. Conclusion: More research is needed to estimate effectiveness of these interventions.

\section{Background}

The world population is aging rapidly. By 2050, it is expected that the population over the age of 60 years will have increased by 2 billion people since the beginning of $21^{\text {st }}$ century [1]. The number of people over 65 in the UK today is $18 \%$ of the total population [2]. By 2030, it is estimated that this number will rise to $21.8 \%$ [1] and there will be greater demands on health and social services [3] as older people experience multiple health problems such as arthritis, diabetes, dementia and cancer $[2,3]$ and geriatric syndromes such as frailty, falls and immobility $[4,5]$.

There is an increased need to develop strategies that promote healthy ageing and an emerging area of interest is digital health [6]. Digital health interventions use digital-based technology to deliver accessible, usable, cost-effective, and measurable interventions to improve health, health care services, and quality of life of people or communities [7]. These technologies include to telehealth, electronic and mobile health applications (ehealth, mhealth), wearable devices and sensors, text messages, e mails. They also potentially offer increased access to treatments from home, reducing the time, physical effort and travel costs of attending appointments [6].

Technology-assisted health care systems generally focus on specific population groups, such as older people and patients with chronic diseases [8]. Common interventions include self-monitoring and management of chronic diseases, patient education medication reviews, promotion of physical activity and exercise, healthy eating and cognitive behavioural therapies [9].

In this review, we focus on digital physical rehabilitation interventions that are designed to improve and restore physical functioning in older people. There are different ways to deliver digital rehabilitation interventions and options include desktop computers, laptops, tablets, smartphones and their additional sensor systems [7].

Taking part in regular physical activity (PA) and exercise is important for older people to maintain or improve the physical function needed to live independently and main good health [10]. Home exercise programs are often a fundamental part of successful rehabilitation for older people [11]. However, the 
adherence to home exercise programs is often low [11] and older people are more likely to adhere to supervised exercises programmes [12]. Digital interventions have the potential to support older people by providing clinicians with a means of encouraging and motivating patients to undertake exercise and self-management strategies $[6,11]$.

To date, there is only one systematic review of digital interventions in this area, and the study is limited to tele-health to support self-management in older people with chronic disease [13]. However, there is no review available on the effectiveness of rehabilitation interventions delivered via digital routes in older people.

\section{Objectives}

To summarise the evidence on the benefits and harms of digital rehabilitation interventions on outcomes including pain, function and quality of life in older people.

\section{Methods}

\section{Protocol and registration}

The protocol is registered with the International Prospective Register of Systematic Reviews (PROSPERO). The registration number is CRD42018042471 and the protocol is available at, https://www.crd.york.ac.uk/PROSPERO/display record.php?RecordID=42471 [14].

\section{Eligibility Criteria}

a) Studies:

Randomized controlled trials that evaluated the effectiveness of digital rehabilitation interventions specifically designed for older people.

Qualitative studies that reported the patient experience of these interventions. Only peer-reviewed publications in English language were considered. Conference abstracts, dissertations and articles published in other languages were.

b) Population: Men and women above 60 years of age with any chronic physical health condition including falls or mobility problems.

c) Intervention: Self-directed digital rehabilitation interventions focusing on physical health delivered via web-based, online platform, mobile applications were included. Digital rehabilitation interventions delivered by health professionals in clinical settings and those used solely for data collection or self-monitoring (e.g. physical activity data collected from a wearable sensor) were excluded.

d) Comparator: The control groups could be either receiving usual care, no treatment, a placebo (a digital rehabilitation intervention with limited features) or a non-digital rehabilitation intervention.

e) Outcomes: The main outcomes include pain, physical activity, function including mobility and fall related outcomes, quality of life, adverse events, and health resource use. Other outcomes of interest were psychological outcomes including self-efficacy, fear avoidance, anxiety, and depression, and process outcomes such as intervention adherence rate and user perspectives. 
f) Timing: Outcomes were categorized into short-term (up to 3 months), medium-term ( $>3$ to 11 months) and long-term (12 months and beyond).

\section{Information Sources}

We searched the electronic databases of Ovid Medline (1946 to 06 November 2018), Ovid Embase (1974 to 06 November 2018), EBSCO CINAHL, the Cochrane Central Register of Controlled Trials (CENTRAL), and Physiotherapy Evidence Database (PEDro). We also searched the Journal of Medical Internet Research (JMIR) and its PubMed-indexed sister journals to identify additional relevant studies. We checked the WHO international clinical trials registry and clinicaltrial.gov trial databases for any ongoing trials.

\section{Search Strategy}

We developed a search strategy (Supplementary file 1) in consultation with a health sciences librarian at the University of Oxford. The strategy was adapted for each bibliographic database. We used simple key words to search the JMIR and the trial databases.

\section{Study Selection}

Two review authors (ET and CS) independently screened the titles and abstracts to identify potential studies from the database searches. ET and CS then screened the full-text publications of the potential studies based on the predefined eligibility criteria of the review. The reasons for excluding studies were documented. ET and CS consulted a third review author (EW) to resolve any disagreements during the study selection process.

\section{Data collection process}

The review authors ET and CS independently extracted the data from the eligible studies using the data extraction forms developed for the review. Data were collected on citation details, participants (age, gender, ethnicity, and education level), inclusion-exclusion criteria, outcomes, interventions and the results. ET and CS cross-checked the data entries and resolved any discrepancies by consulting EW, the other review author. If date was insufficient for reporting from the included studies, ET attempted to contact the corresponding authors via email with up to three reminders.

\section{Risk of bias in individual studies}

The review authors ET and CS used the Cochrane risk of bias tool to evaluate the risk of bias of the included trials. The tool evaluates risk of bias arising from randomization (Selection bias), effect of assignment to interventions (Performance bias), measuring outcomes (Detection bias) and missing data (Reporting Bias) and other sources of bias such as baseline variability between groups and small sample size. ET and CS summarized the overall risk of bias for each study as high, unclear, and low as per the Cochrane guidelines. Studies are assessed at overall low risk of bias if all key domains were rated low risk; unclear risk if one or more key domains is rated unclear; and high risk if one or more key domains are rated at high risk. Any disagreements were resolved by consulting EW. 


\section{Summary measures}

We proposed to calculate the treatment estimates as mean difference or standardised mean difference for continuous outcomes and risk ratio for dichotomous outcomes with $95 \%$ confidence interval at short, medium and long-term.

\section{Synthesis of results}

Before undertaking this review, it was unknown if it would be possible to carry out meta-analysis. Therefore, we specified statistical heterogeneity $\mathrm{I}^{2}$ at $75 \%$ as cut point to determine that meta-analysis was not appropriate. The clinical heterogeneity was judged by the review authors based on the similarities and differences between participants, interventions and the outcome measures used in the included studies.

\section{Grading of evidence}

We used the Cochrane's Grading of Recommendations, Assessment, Development and Evaluation (GRADE) approach $[15,16]$ to evaluate the quality of evidence as high, moderate, low or very low for the main outcomes of the review.

\section{Results}

\section{Study Selection}

Figure 1 shows the study selection process. A total of 35,835 records were identified from the database searches (16,366 from Medline, 15,361 from EMBASE, 3623 from CINAHL, and 454 from PEDro). Additional records were identified by searching the Journal of Medical Internet Research (JMIR) journal and its PubMed indexed sister journals. After screening full-text articles, 8 trials $[10,17-23]$ were determined eligible for our review. One trial was reported in two publications [18-19]. Therefore, a total of seven trials were included.

We did not identify any qualitative studies that explored older peoples' experience of digital rehabilitation interventions.

\section{Study Characteristics}

Of the seven trials, five trials focused on increasing physical activity [10, 17-19, 22-23]. One trial included a vestibular rehabilitation programme for dizziness [20], and the other evaluated a falls prevention programme [21]. The interventions were delivered via a tablet in two trials [17,21], web connected pedometer in two trials [17,23], accelerometer in one trial [18]. One trial used a combination of virtual animation coach and computer games with Kinect sensor [17]

The characteristics of the included trials are shown in Table 1. Three trials were from the United States of America [10, 17, 23]; two from Europe [18-19, 22]; and one each from Australia [21] and the United Kingdom [20]. The sample size ranged from 102 to 415 . Three trials provided no intervention to those in the control arm [10, 22, and 23]. Two trials delivered usual care/education [17, 20, and 21] and one trial used a wait list control [18-19]. The duration of digital rehabilitation interventions ranged from 6 weeks to 4 months. The components of the interventions were mapped to the Behavioural Intervention Technology (BIT) model and presented in Table 2.

The most commonly evaluated outcome was physical activity [10, 17-19, 22-23], followed by quality of life [10,18-19]. Other outcomes included disability or function (two trials), adverse events (two trials), fall risk (one trial), vestibular symptoms (one trial), psychological measures ( 2 trials), user perspective (three trials), and intervention adherence (two trials). All trials reported short-term follow- 
up results. The medium-term long-term effects were reported in one trial each. The medium-term was reported in one trial [10] and long-term effects in two trials 17, 22].

\section{Methodological Quality}

The bias assessment of the included trials is shown in Table 3. The overall risk of bias was rated as unclear for two trials [20,22] and high risk for 5 trials [10, 17-19, 23]. The high risk of bias was due to lack of blinding of participants and personnel delivering the interventions. Trials were predominantly rated as high risk of bias due to lack of blinding of participants and personnel delivering the interventions. Assessing outcomes were blinded in five of seven studies. While one study was conducted with over 400 participants, the number of participants ranged from 102 to 263 in other studies. Participants were recruited via online requirement strategies (eg, social media, websites, emails, newsletters) in four studies $[10,18,19,22,23]$. iStoppFalls study was carried out multicenter requirement. One trial was single centered [20] and other study were required the adults from three outpatient clinics[17].

\section{Outcomes}

We concluded that data could not be pooled due to heterogeneous nature of the participants, interventions and outcome measures. Therefore, a narrative summary of the effects of digital rehabilitation interventions on the outcomes is presented (Tables 4 and 5).

\section{Physical activity}

Pedometer, accelerometer and the International Physical Activity Questionnaire (IPAQ) were used to assess physical activity in five trials (Table 3). It appears that web-based interventions do increase physical activity in short/medium term with all studies reporting improvements compared to the control intervention. Two studies found that web based PA interventions is effective for increasing step count in the short term [17, 23]. Irvene et.al [10] reported that web-based PA interventions are effective in both the short and medium term at increasing the time being physically active by evaluating the total minute physical activity for a week in cardiovascular activities, stretching activities, strengthening activities, balance [10].

No difference was observed in outcomes at 12 months.

\section{Quality of life}

Three trials evaluated quality of life. Two of these were physical activity interventions $[10,19]$. One trial reported significant effects favouring digital rehabilitation interventions in the short and medium term (Irvine). Broekhuizen [19] only reported a significant improvement for emotional-mental subscale score of the Research and Development 36 item Health Survey/ RAND 36. There were no significant difference in quality of life for digital vestibular training in short term [21].

\section{Vestibular and Fall Risk Outcomes}


Digital-based vestibular training was found effective in both short and medium term for vertigo symptoms [20]. One trial focused on fall risk and reported that digital rehabilitation reduces the physiological fall risk [21].

\section{Disability}

The impact of digital rehabilitation interventions on disability/function was reported in two trials. One trial that evaluated a balance retraining programme [20] found a significant reduction in dizziness related disability using the Dizziness Handicap Inventory compare to control group. Another trial on a falls prevention programme [21] measured general health (including mobility, activities, participation, and self-care) using the World Health Organisation Disability Assessment Schedule (WHODAS) 2. No significant difference was found between the intervention and control groups.

Adverse events

Only two trials reported adverse events. The iStoppFall study reported that there were no adverse events in the study [21]. Bickmore et al [17] reported 289 adverse events of which 10 were moderate-severe events that were likely be not related to digital intervention ( 8 in control 2 in intervention group) [17].

Pain

None of the included trials evaluated this outcome.

Health resource use

None of the included trials evaluated this outcome.

\section{Psychological outcomes}

Anxiety

Gearagty et. al [20] found a greater reduction in anxiety at 3 months in intervention group measured by the HADS (Hospital Anxiety and Depression Scale) compared to the control, but this difference was not sustained at 6 months.

\section{Depression}

Digital vestibular rehabilitation intervention had no significant effect on depression at three or six months compared to the control intervention [20]. Similarly, the iStoppFalls study reported no significant difference in a measure of depression between intervention and usual care groups study [21].

\section{Self-efficacy}

None of the included trials evaluated this outcome.

Fear avoidance

None of the included trials evaluated this outcome.

\section{Process outcomes}




\section{Intervention adherence}

Only 2 trials reported data on intervention adherence which was determined by number of times they accessed the web based intervention or completion rates of the programme. Bickmore et al [17] reported that the embodied conversational agent-based PA intervention participants interacted with the virtual coach at an average of $35 \pm 19$ times during the 2-month intervention. Wishman et al determined that $91.2 \%$ of participants completed the web-based program [18]. None of the studies used the adherence to digital intervention as a primary assessment measure and did not evaluate the adherence by a patient reported scale or questionnaires. In other words, the evaluations and results related to intervention adherence in the studies are insufficient. Therefore, it is not possible to conclude about intervention adherence with limited findings.

\section{Intervention Attrition}

Two studies that compare the efficacy of an online PA intervention reported small dropout rates (Bickmore, et al $=3 \%$, Broekhuizen, et al. $=6.7 \%$ ) for intervention attrition. One study which assessed the effectiveness web-based fall prevention program has similar dropout rates between intervention and control group ( $\mathrm{n}=52,15$ drop out from intervention group, 13 dropouts from control group). Two studies reported high level of intervention attrition rates. Irvene et. al reported that $36.5 \%$ participants didn't completed the all sessions. Besides, a study that compare the effectiveness of an online vestibular rehabilitation reported high attrition as $23 \%$ [21].

\section{User perspectives}

User satisfaction were evaluated in two trials. [10, 17]. Both trials used a Likert scale (1 to 7$)$ to measure participants' satisfaction, and Both of them reported an average score of 6 (quite satisfied). In Irvene et al [10], participants also rated the program as very easy to use and very helpful, and, they would recommend the program to friends or family (7-point scale, mean=5.7 \pm 1.4 ).

\section{Quality of Evidence}

The quality of evidence for the main outcomes of the review are presented in Table 6 .

\section{Physical activity}

In the short term, digital rehabilitation interventions may improve physical activity in older adults compared to no intervention or waiting list but the evidence is of moderate quality. It is uncertain whether they are effective compared to a pedometer only intervention as although results favour the digital intervention it is based on very low quality evidence.

In the medium term, digital rehabilitation interventions probably improve physical activity compared to no intervention (Moderate evidence).

In the long term, it is uncertain whether digital rehabilitation interventions have no effect compared to no intervention or a pedometer-based intervention as this based on one study and the evidence is very low quality evidence.

Quality of life 


\section{Discussion}

This review evaluated the effectiveness and safety of digital rehabilitation interventions in people over 60 years of age. We included seven randomized controlled trials to this review. These trials compared digital rehabilitation interventions that focused on physical activity, falls prevention and vestibular retraining to a range of control interventions (usual care, education, no intervention or waiting list). The findings suggest that digital health interventions may improve physical activity and quality of life in the medium term (Moderate evidence). However, there is inconclusive evidence for the short-term effects on physical activity, quality of life (physical and mental domains), vertigo symptoms and falls risk due to risk of bias, indirectness of evidence, and small sample sizes. There was a lack of consistency on the effects on quality of life. The long term effects on physical activity is unknown. Further research has the potential to change these findings. Only 2 studies included long term follow up and no difference between interventions was observed.

Secondary outcomes of interest that were studied included anxiety, depression, satisfaction, adherence, and trial attrition. None of the included trials evaluated health resource use outcomes, pain, and selfefficacy or fear avoidance behavior. There were very few adverse events reported that are likely to be related to the interventions but only 2 trials actually reported adverse events so the safety profile of this type of intervention is unclear.

A range of methods were used by the studies in this review. Only 2 trials measured satisfaction with the interventions but both suggested that these were acceptable interventions for older people and engagement was good. A recent systematic review concluded that tablet technology is acceptable and satisfying to older people, even if they have cognitive disorders [29]. Acceptability of digital rehabilitation interventions to older people is important if we want older people to access care in this way. Notably there were no trials in this review using Smartphone which are in very common use, although, we are aware of a feasibility trial that is underway in the UK to evaluate an intervention delivered via Smartphone technology to support home exercises and prevent falls [31] . 
The majority of trials in this review focused on increasing physical activity [10, 17, 18, 19, 22, and 23]. Physical activity is a key target for health improvement or disease prevention in in older people. Prior systematic reviews specified that population-based strategies with the use of e-health to promote PA are effective [27]. Our findings would suggest there is also potential to improve physical activity as a rehabilitation strategy using digital rehabilitation interventions. All the interventions required participants to interact with the digital application on a daily or weekly basis. Mouton and Irvene noted that engagement with the programme was better when the programme was supervised.

The prevention of falls is another treatment target to improve health outcomes in older people. Nearly one in three older people aged over 65 experience a fall at least once a year and results in a large social and economic burden on individuals, and health services. Exercise is an effective strategy for preventing falls and digital rehabilitation interventions have the potential to make this type of treatment accessible to large numbers of older people [5]. There was only one trial included in this review that focused on balance training [21]. And it utilized game technology to deliver balance and strengthening exercises, a feature distinguishing it from other studies in this review. However, the system used in this trial contained a lot of additional technologies such as Kinect sensor systems, accelerometer, Google TV set, and computers/tablets. The digital fall-stop intervention program reduced the physiological fall risk for older people, but further research is needed including testing more simple technologies which would make the intervention more accessible. The final trial in this review focused on vestibular rehabilitation and resulted in reduced dizziness and disability compared to the control [20]. Demonstrating that this type of intervention can successfully be delivered using a digital approach overcoming economic barriers and increasing accessibility [20]. In all studies, the control groups were 'usual care' or 'no treatment'. Although this had been noted as BIAS for comparators, the comparison of the included studies has been consistent since all studies are similar.

\section{Limitations}

The review focused on physical rehabilitation interventions for older people delivered using digital platforms. This meant we excluded studies that used for tele-rehabilitation (telephone calls or messaging) which appeared to be more common in the literature and therefore resulted in a small number of studies. Although, 5 of the seven trials focused on physical activity, we were unable perform metaanalysis because of heterogeneity in the included studies. It was not possible to blind participants and personnel to the intervention received by participants so all studies were considered high risk for this element of the risk of bias assessment making it impossible for studies to be considered low risk of bias according to the Cochrane risk of bias tool.

\section{Conclusions}

Digital rehabilitation interventions seem to have potential to benefit older people in improving physical activity and quality of life in the medium term. However, there is uncertainty around the short-term effects on physical activity, quality of life (physical and mental domains), vertigo symptoms and falls. More research is needed to establish robust estimates of effectiveness including long-term outcomes. There is a need to conduct large trials that include evaluation of cost-effectiveness and safety of these interventions for older people. 


\section{Components, design, and effectiveness of digital physical rehabilitation interventions for older people: a systematic review.}

\section{Summary}

Background: With the rapid advancement in digital technologies, the use of digital health applications is increasing day by day. Although a large number of digital applications have been developed for rehabilitation of older people, there has been no review of the evidence for effectiveness of these interventions. Methods: The aim of our study was to review the evidence of digital rehabilitation interventions on outcomes including pain, function and quality of life in older people. We focus on digital interventions that are designed to improve and restore physical functioning. We searched six electronic bibliographic databases and included randomized controlled trials. Cochrane risk of bias tool and Cochrane's GRADE's_approach were used to evaluate the risk of bias and grad the evidence. Results: Eight trials were included. The short-term effects of digital rehabilitation interventions on physical activity, quality of life, vertigo symptoms and falls are uncertain. Quality of trials were rated as very low to moderate evidence. Conclusion: More research is needed to estimate effectiveness of these interventions.

\section{Background}

The world population is aging rapidly. By 2050, it is expected that the population over the age of 60 years will have increased by 2 billion people since the beginning of $21^{\text {st }}$ century [1]. The number of people over 65 in the UK today is $18 \%$ of the total population [2]. By 2030, it is estimated that this number will rise to $21.8 \%$ [1] and there will be greater demands on health and social services [3] as older people experience multiple health problems such as arthritis, diabetes, dementia and cancer [2,3] and geriatric syndromes such as frailty, falls and immobility $[4,5]$.

There is an increased need to develop strategies that promote healthy ageing and an emerging area of interest is digital health [6]. Digital health interventions use digital-based technology to deliver accessible, usable, cost-effective, and measurable interventions to improve health, health care services, and quality of life of people or communities [7]. These technologies include to telehealth, electronic and mobile health applications (ehealth, mhealth), wearable devices and sensors, text messages, e mails. They also potentially offer increased access to treatments from home, reducing the time, physical effort and travel costs of attending appointments [6].

Technology-assisted health care systems generally focus on specific population groups, such as older people and patients with chronic diseases [8]. Common interventions include self-monitoring and management of chronic diseases, patient education medication reviews, promotion of physical activity and exercise, healthy eating and cognitive behavioural therapies [9].

In this review, we focus on digital physical rehabilitation interventions that are designed to improve and restore physical functioning in older people. There are different ways to deliver digital rehabilitation interventions and options include desktop computers, laptops, tablets, smartphones and their additional sensor systems [7].

Taking part in regular physical activity (PA) and exercise is important for older people to maintain or improve the physical function needed to live independently and main good health [10]. Home exercise programs are often a fundamental part of successful rehabilitation for older people [11]. However, the 
adherence to home exercise programs is often low [11] and older people are more likely to adhere to supervised exercises programmes [12]. Digital interventions have the potential to support older people by providing clinicians with a means of encouraging and motivating patients to undertake exercise and self-management strategies $[6,11]$.

To date, there is only one systematic review of digital interventions in this area, and the study is limited to tele-health to support self-management in older people with chronic disease [13]. However, there is no review available on the effectiveness of rehabilitation interventions delivered via digital routes in older people.

\section{Objectives}

To summarise the evidence on the benefits and harms of digital rehabilitation interventions on outcomes including pain, function and quality of life in older people.

\section{Methods}

\section{Protocol and registration}

The protocol is registered with the International Prospective Register of Systematic Reviews (PROSPERO). The registration number is CRD42018042471 and the protocol is available at, https://www.crd.york.ac.uk/PROSPERO/display record.php?RecordID=42471 [14].

\section{Eligibility Criteria}

a) Studies:

Randomized controlled trials that evaluated the effectiveness of digital rehabilitation interventions specifically designed for older people.

Qualitative studies that reported the patient experience of these interventions. Only peer-reviewed publications in English language were considered. Conference abstracts, dissertations and articles published in other languages were.

b) Population: Men and women above 60 years of age with any chronic physical health condition including falls or mobility problems.

c) Intervention: Self-directed digital rehabilitation interventions focusing on physical health delivered via web-based, online platform, mobile applications were included. Digital rehabilitation interventions delivered by health professionals in clinical settings and those used solely for data collection or self-monitoring (e.g. physical activity data collected from a wearable sensor) were excluded.

d) Comparator: The control groups could be either receiving usual care, no treatment, a placebo (a digital rehabilitation intervention with limited features) or a non-digital rehabilitation intervention.

e) Outcomes: The main outcomes include pain, physical activity, function including mobility and fall related outcomes, quality of life, adverse events, and health resource use. Other outcomes of interest were psychological outcomes including self-efficacy, fear avoidance, anxiety, and depression, and process outcomes such as intervention adherence rate and user perspectives. 
f) Timing: Outcomes were categorized into short-term (up to 3 months), medium-term ( $>3$ to 11 months) and long-term (12 months and beyond).

\section{Information Sources}

We searched the electronic databases of Ovid Medline (1946 to 06 November 2018), Ovid Embase (1974 to 06 November 2018), EBSCO CINAHL, the Cochrane Central Register of Controlled Trials (CENTRAL), and Physiotherapy Evidence Database (PEDro). We also searched the Journal of Medical Internet Research (JMIR) and its PubMed-indexed sister journals to identify additional relevant studies. We checked the WHO international clinical trials registry and clinicaltrial.gov trial databases for any ongoing trials.

\section{Search Strategy}

We developed a search strategy (Supplementary file 1) in consultation with a health sciences librarian at the University of Oxford. The strategy was adapted for each bibliographic database. We used simple key words to search the JMIR and the trial databases.

\section{Study Selection}

Two review authors (ET and CS) independently screened the titles and abstracts to identify potential studies from the database searches. ET and CS then screened the full-text publications of the potential studies based on the predefined eligibility criteria of the review. The reasons for excluding studies were documented. ET and CS consulted a third review author (EW) to resolve any disagreements during the study selection process.

\section{Data collection process}

The review authors ET and CS independently extracted the data from the eligible studies using the data extraction forms developed for the review. Data were collected on citation details, participants (age, gender, ethnicity, and education level), inclusion-exclusion criteria, outcomes, interventions and the results. ET and CS cross-checked the data entries and resolved any discrepancies by consulting EW, the other review author. If date was insufficient for reporting from the included studies, ET attempted to contact the corresponding authors via email with up to three reminders.

\section{Risk of bias in individual studies}

The review authors ET and CS used the Cochrane risk of bias tool to evaluate the risk of bias of the included trials. The tool evaluates risk of bias arising from randomization (Selection bias), effect of assignment to interventions (Performance bias), measuring outcomes (Detection bias) and missing data (Reporting Bias) and other sources of bias such as baseline variability between groups and small sample size. ET and CS summarized the overall risk of bias for each study as high, unclear, and low as per the Cochrane guidelines. Studies are assessed at overall low risk of bias if all key domains were rated low risk; unclear risk if one or more key domains is rated unclear; and high risk if one or more key domains are rated at high risk. Any disagreements were resolved by consulting EW. 


\section{Summary measures}

We proposed to calculate the treatment estimates as mean difference or standardised mean difference for continuous outcomes and risk ratio for dichotomous outcomes with $95 \%$ confidence interval at short, medium and long-term.

Synthesis of results

Before undertaking this review, it was unknown if it would be possible to carry out meta-analysis. Therefore, we specified statistical heterogeneity $\mathrm{I}^{2}$ at $75 \%$ as cut point to determine that meta-analysis was not appropriate. The clinical heterogeneity was judged by the review authors based on the similarities and differences between participants, interventions and the outcome measures used in the included studies.

\section{Grading of evidence}

We used the Cochrane's Grading of Recommendations, Assessment, Development and Evaluation (GRADE) approach $[15,16]$ to evaluate the quality of evidence as high, moderate, low or very low for the main outcomes of the review.

\section{Results}

\section{Study Selection}

Figure 1 shows the study selection process. A total of 35,835 records were identified from the database searches (16,366 from Medline, 15,361 from EMBASE, 3623 from CINAHL, and 454 from PEDro). Additional records were identified by searching the Journal of Medical Internet Research (JMIR) journal and its PubMed indexed sister journals. After screening full-text articles, 8 trials [10, 17-23] were determined eligible for our review. One trial was reported in two publications [18-19]. Therefore, a total of seven trials were included.

We did not identify any qualitative studies that explored older peoples' experience of digital rehabilitation interventions.

\section{Study Characteristics}

Of the seven trials, five trials focused on increasing physical activity [10, 17-19, 22-23]. One trial included a vestibular rehabilitation programme for dizziness [20], and the other evaluated a falls prevention programme [21]. The interventions were delivered via a tablet in two trials [17, 21], web connected pedometer in two trials [17,23], accelerometer in one trial [18]. One trial used a combination of virtual animation coach and computer games with Kinect sensor [17]

The characteristics of the included trials are shown in Table 1. Three trials were from the United States of America [10, 17, 23]; two from Europe [18-19, 22]; and one each from Australia [21] and the United Kingdom [20]. The sample size ranged from 102 to 415 . Three trials provided no intervention to those in the control arm [10, 22, and 23]. Two trials delivered usual care/education [17, 20, and 21] and one trial used a wait list control [18-19]. The duration of digital rehabilitation interventions ranged from 6 weeks to 4 months. The components of the interventions were mapped to the Behavioural Intervention Technology (BIT) model and presented in Table 2.

The most commonly evaluated outcome was physical activity [10, 17-19, 22-23], followed by quality of life [10, 18-19]. Other outcomes included disability or function (two trials), adverse events (two trials), fall risk (one trial), vestibular symptoms (one trial), psychological measures (2 trials), user perspective (three trials), and intervention adherence (two trials). All trials reported short-term follow- 
up results. The medium-term long-term effects were reported in one trial each. The medium-term was reported in one trial [10] and long-term effects in two trials 17, 22].

\section{Methodological Quality}

The bias assessment of the included trials is shown in Table 3. The overall risk of bias was rated as unclear for two trials [20,22] and high risk for 5 trials $[10,17-19,23]$. The high risk of bias was due to lack of blinding of participants and personnel delivering the interventions. Trials were predominantly rated as high risk of bias due to lack of blinding of participants and personnel delivering the interventions. Assessing outcomes were blinded in five of seven studies. While one study was conducted with over 400 participants, the number of participants ranged from 102 to 263 in other studies. Participants were recruited via online requirement strategies (eg, social media, websites, emails, newsletters) in four studies $[10,18,19,22,23]$. iStoppFalls study was carried out multicenter requirement. One trial was single centered [20] and other study were required the adults from three outpatient clinics[17].

\section{Outcomes}

We concluded that data could not be pooled due to heterogeneous nature of the participants, interventions and outcome measures. Therefore, a narrative summary of the effects of digital rehabilitation interventions on the outcomes is presented (Tables 4 and 5).

\section{Physical activity}

Pedometer, accelerometer and the International Physical Activity Questionnaire (IPAQ) were used to assess physical activity in five trials (Table 3). It appears that web-based interventions do increase physical activity in short/medium term with all studies reporting improvements compared to the control intervention. Two studies found that web based PA interventions is effective for increasing step count in the short term [17, 23]. Irvene et.al [10] reported that web-based PA interventions are effective in both the short and medium term at increasing the time being physically active by evaluating the total minute physical activity for a week in cardiovascular activities, stretching activities, strengthening activities, balance [10].

No difference was observed in outcomes at 12 months.

\section{Quality of life}

Three trials evaluated quality of life. Two of these were physical activity interventions $[10,19]$. One trial reported significant effects favouring digital rehabilitation interventions in the short and medium term (Irvine). Broekhuizen [19] only reported a significant improvement for emotional-mental subscale score of the Research and Development 36 item Health Survey/ RAND 36. There were no significant difference in quality of life for digital vestibular training in short term [21].

\section{Vestibular and Fall Risk Outcomes}


Digital-based vestibular training was found effective in both short and medium term for vertigo symptoms [20]. One trial focused on fall risk and reported that digital rehabilitation reduces the physiological fall risk [21].

\section{Disability}

The impact of digital rehabilitation interventions on disability/function was reported in two trials. One trial that evaluated a balance retraining programme [20] found a significant reduction in dizziness related disability using the Dizziness Handicap Inventory compare to control group. Another trial on a falls prevention programme [21] measured general health (including mobility, activities, participation, and self-care) using the World Health Organisation Disability Assessment Schedule (WHODAS) 2. No significant difference was found between the intervention and control groups.

Adverse events

Only two trials reported adverse events. The iStoppFall study reported that there were no adverse events in the study [21]. Bickmore et al [17] reported 289 adverse events of which 10 were moderate-severe events that were likely be not related to digital intervention ( 8 in control 2 in intervention group) [17].

Pain

None of the included trials evaluated this outcome.

Health resource use

None of the included trials evaluated this outcome.

\section{Psychological outcomes}

Anxiety

Gearagty et. al [20] found a greater reduction in anxiety at 3 months in intervention group measured by the HADS (Hospital Anxiety and Depression Scale) compared to the control, but this difference was not sustained at 6 months.

\section{Depression}

Digital vestibular rehabilitation intervention had no significant effect on depression at three or six months compared to the control intervention [20]. Similarly, the iStoppFalls study reported no significant difference in a measure of depression between intervention and usual care groups study [21].

Self-efficacy

None of the included trials evaluated this outcome.

Fear avoidance

None of the included trials evaluated this outcome.

\section{Process outcomes}




\section{Intervention adherence}

Only 2 trials reported data on intervention adherence which was determined by number of times they accessed the web based intervention or completion rates of the programme. Bickmore et al [17] reported that the embodied conversational agent-based PA intervention participants interacted with the virtual coach at an average of $35 \pm 19$ times during the 2-month intervention. Wishman et al determined that $91.2 \%$ of participants completed the web-based program [18]. None of the studies used the adherence to digital intervention as a primary assessment measure and did not evaluate the adherence by a patient reported scale or questionnaires. In other words, the evaluations and results related to intervention adherence in the studies are insufficient. Therefore, it is not possible to conclude about intervention adherence with limited findings.

\section{Intervention Attrition}

Two studies that compare the efficacy of an online PA intervention reported small dropout rates (Bickmore, et $\mathrm{al}=3 \%$, Broekhuizen, et al. $=6.7 \%$ ) for intervention attrition. One study which assessed the effectiveness web-based fall prevention program has similar dropout rates between intervention and control group ( $\mathrm{n}=52,15$ drop out from intervention group, 13 dropouts from control group). Two studies reported high level of intervention attrition rates. Irvene et. al reported that $36.5 \%$ participants didn't completed the all sessions. Besides, a study that compare the effectiveness of an online vestibular rehabilitation reported high attrition as $23 \%$ [21].

\section{User perspectives}

User satisfaction were evaluated in two trials. [10, 17]. Both trials used a Likert scale (1 to 7$)$ to measure participants' satisfaction, and Both of them reported an average score of 6 (quite satisfied). In Irvene et al [10], participants also rated the program as very easy to use and very helpful, and, they would recommend the program to friends or family (7-point scale, mean=5.7 \pm 1.4 ).

\section{Quality of Evidence}

The quality of evidence for the main outcomes of the review are presented in Table 6 .

\section{Physical activity}

In the short term, digital rehabilitation interventions may improve physical activity in older adults compared to no intervention or waiting list but the evidence is of moderate quality. It is uncertain whether they are effective compared to a pedometer only intervention as although results favour the digital intervention it is based on very low quality evidence.

In the medium term, digital rehabilitation interventions probably improve physical activity compared to no intervention (Moderate evidence).

In the long term, it is uncertain whether digital rehabilitation interventions have no effect compared to no intervention or a pedometer-based intervention as this based on one study and the evidence is very low quality evidence.

\section{Quality of life}


In the short term, it is uncertain whether digital rehabilitation interventions have or do not have an effect on the QoL-physical domain compared to no intervention or waiting list due to inconsistent findings based on very low quality evidence. They may slightly improve QoL-mental domain compared to no intervention or waiting list (Low quality evidence). It is uncertain whether digital rehabilitation interventions have no effect on the overall QoL, compared to education only due to very low quality evidence.

In the medium term, digital rehabilitation interventions probably improve individual physical and mental domains compared to no intervention (Moderate evidence).

\section{Vertigo symptoms}

In the short and medium term, it is uncertain whether digital rehabilitation interventions are effective in improving vertigo symptoms than the usual care as although results favours the digital intervention it is based on very low quality evidence.

\section{Falls risk}

In the short-term, it is uncertain whether digital rehabilitation interventions are effective in reducing falls risk than a falls prevention education programme as although results favours the digital intervention it is based on very low quality evidence.

\section{Discussion}

This review evaluated the effectiveness and safety of digital rehabilitation interventions in people over 60 years of age. We included seven randomized controlled trials to this review. These trials compared digital rehabilitation interventions that focused on physical activity, falls prevention and vestibular retraining to a range of control interventions (usual care, education, no intervention or waiting list). The findings suggest that digital health interventions may improve physical activity and quality of life in the medium term (Moderate evidence). However, there is inconclusive evidence for the short-term effects on physical activity, quality of life (physical and mental domains), vertigo symptoms and falls risk due to risk of bias, indirectness of evidence, and small sample sizes. There was a lack of consistency on the effects on quality of life. The long term effects on physical activity is unknown. Further research has the potential to change these findings. Only 2 studies included long term follow up and no difference between interventions was observed.

Secondary outcomes of interest that were studied included anxiety, depression, satisfaction, adherence, and trial attrition. None of the included trials evaluated health resource use outcomes, pain, and selfefficacy or fear avoidance behavior. There were very few adverse events reported that are likely to be related to the interventions but only 2 trials actually reported adverse events so the safety profile of this type of intervention is unclear.

A range of methods were used by the studies in this review. Only 2 trials measured satisfaction with the interventions but both suggested that these were acceptable interventions for older people and engagement was good. A recent systematic review concluded that tablet technology is acceptable and satisfying to older people, even if they have cognitive disorders [29]. Acceptability of digital rehabilitation interventions to older people is important if we want older people to access care in this way. Notably there were no trials in this review using Smartphone which are in very common use, although, we are aware of a feasibility trial that is underway in the UK to evaluate an intervention delivered via Smartphone technology to support home exercises and prevent falls [31]. 
The majority of trials in this review focused on increasing physical activity [10, 17, 18, 19, 22, and 23]. Physical activity is a key target for health improvement or disease prevention in in older people. Prior systematic reviews specified that population-based strategies with the use of e-health to promote PA are effective [27]. Our findings would suggest there is also potential to improve physical activity as a rehabilitation strategy using digital rehabilitation interventions. All the interventions required participants to interact with the digital application on a daily or weekly basis. Mouton and Irvene noted that engagement with the programme was better when the programme was supervised.

The prevention of falls is another treatment target to improve health outcomes in older people. Nearly one in three older people aged over 65 experience a fall at least once a year and results in a large social and economic burden on individuals, and health services. Exercise is an effective strategy for preventing falls and digital rehabilitation interventions have the potential to make this type of treatment accessible to large numbers of older people [5]. There was only one trial included in this review that focused on balance training [21]. And it utilized game technology to deliver balance and strengthening exercises, a feature distinguishing it from other studies in this review. However, the system used in this trial contained a lot of additional technologies such as Kinect sensor systems, accelerometer, Google TV set, and computers/tablets. The digital fall-stop intervention program reduced the physiological fall risk for older people, but further research is needed including testing more simple technologies which would make the intervention more accessible. The final trial in this review focused on vestibular rehabilitation and resulted in reduced dizziness and disability compared to the control [20]. Demonstrating that this type of intervention can successfully be delivered using a digital approach overcoming economic barriers and increasing accessibility [20]. In all studies, the control groups were 'usual care' or 'no treatment'. Although this had been noted as BIAS for comparators, the comparison of the included studies has been consistent since all studies are similar.

\section{Limitations}

The review focused on physical rehabilitation interventions for older people delivered using digital platforms. This meant we excluded studies that used for tele-rehabilitation (telephone calls or messaging) which appeared to be more common in the literature and therefore resulted in a small number of studies. Although, 5 of the seven trials focused on physical activity, we were unable perform metaanalysis because of heterogeneity in the included studies. It was not possible to blind participants and personnel to the intervention received by participants so all studies were considered high risk for this element of the risk of bias assessment making it impossible for studies to be considered low risk of bias according to the Cochrane risk of bias tool.

\section{Conclusions}

Digital rehabilitation interventions seem to have potential to benefit older people in improving physical activity and quality of life in the medium term. However, there is uncertainty around the short-term effects on physical activity, quality of life (physical and mental domains), vertigo symptoms and falls. More research is needed to establish robust estimates of effectiveness including long-term outcomes. There is a need to conduct large trials that include evaluation of cost-effectiveness and safety of these interventions for older people. 


\section{References}

1) United Nations DoEaSA, Population Division World Population Ageing 2017 Highlights 2017.

2) AgeUK. Later life in United Kingdom 2019 [Available from: https://www.ageuk.org.uk/our-impact/policy-research/policy-positions/

3) Kingston A, Comas-Herrera A, Jagger C. Forecasting the care needs of the older population in England over the next 20 years: estimates from the Population Ageing and Care Simulation (PACSim) modelling study. The Lancet Public Health. 2018; 3(9):e447e55.

4) Inouye SK, Studenski S, Tinetti ME, Kuchel GA. Geriatric syndromes: clinical, research, and policy implications of a core geriatric concept. J Am Geriatr Soc. 2007; 55(5):780-91.

5) Sherrington C, Michaleff ZA, Fairhall N, Paul SS, Tiedemann A, Whitney J, et al. Exercise to prevent falls in older adults: an updated systematic review and meta-analysis. Br J Sports Med. 2017; 51(24):1750-8.

6) Robbins TD, Lim Choi Keung SN, Arvanitis TN. E-health for active ageing; A systematic review. Maturitas. 2018; 114:34-40.

7) World Health Organization. Classification of digital health interventions v1. 0: a shared language to describe the uses of digital technology for health. World Health Organization; 2018.

8) Stellefson M, Chaney B, Barry AE, Chavarria E, Tennant B, Walsh-Childers K, et al. Web 2.0 Chronic Disease Self-Management for Older Adults: A Systematic Review. J Med Internet Res. 2013; 15(2):e35.

9) Gagnon MP, Ndiaye MA, Larouche A, Chabot G, Chabot C, Buyl R, et al. Optimising patient active role with a user-centred eHealth platform $(\mathrm{CONCERTO}+)$ in chronic diseases management: a study protocol for a pilot cluster randomised controlled trial. BMJ Open. 2019; 9(4):e028554.

10) Irvine AB, Gelatt VA, Seeley JR, Macfarlane P, Gau JM. Web-based Intervention to Promote Physical Activity by Sedentary Older Adults: Randomized Controlled Trial. J Med Internet Res. 2013; 15(2):e19.

11) Argent R, Daly A, Caulfield B. Patient Involvement With Home-Based Exercise Programs: Can Connected Health Interventions Influence Adherence? JMIR Mhealth Uhealth. 2018; 6(3):e47.

12) Picorelli AM, Pereira LS, Pereira DS, Felicio D, Sherrington C. Adherence to exercise programs for older people is influenced by program characteristics and personal factors: a systematic review. J Physiother. 2014; 60(3):151-6.

13) Guo Y, Albright D. The effectiveness of telehealth on self-management for older adults with a chronic condition: A comprehensive narrative review of the literature. Journal of telemedicine and telecare. 2018; 24(6):392-403.

14) Cynthia Srikesavan, Eda Tonga, Eli Harriss, Esther Williamson, Sarah E Lamb, Bethan Copsey. Components, design, and effectiveness of digital rehabilitation interventions for older adults: a mixed-method systematic review. NHIR, PROSPERO International prospective register of systematic reviews

15) Cochrane Training. GRADE Handbook URL: https://training.cochrane.org/resource/grade-handbook [accessed 2019-05-31]

16) Bickmore TW, Silliman RA, Nelson K, Cheng DM, Winter M, Henault L, et al. A randomized controlled trial of an automated exercise coach for older adults. Journal of the American Geriatrics Society. 2013; 61(10):1676-83.

17) Wijsman CA, Westendorp RGJ, Verhagen EALM, Catt M, Slagboom PE, De Craen AJM, et al. Effects of a web-based intervention on physical activity and metabolism in 
older adults: Randomized controlled trial. Diabetes Technology and Therapeutics. 2015; 17(Supplement 1):S63-S4.

18) Broekhuizen K, de Gelder J, Wijsman CA, Wijsman LW, Westendorp RG, Verhagen E, et al. An Internet-Based Physical Activity Intervention to Improve Quality of Life of Inactive Older Adults: A Randomized Controlled Trial. J Med Internet Res. 2016; 18(4):e74.

19) Geraghty AW, Kirby S, Essery R, Little P, Bronstein A, Turner D, et al. Internet-based vestibular rehabilitation for adults aged 50 years and over: a protocol for a randomised controlled trial. BMJ Open. 2014; 4(7):e005871.

20) Gschwind YJ, Eichberg S, Ejupi A, de Rosario H, Kroll M, Marston HR, et al. ICT-based system to predict and prevent falls (iStoppFalls): results from an international multicenter randomized controlled trial. Eur Rev Aging Phys Act. 2015; 12:10.

21) Mouton A, Cloes M. Efficacy of a web-based, center-based or combined physical activity intervention among older adults. Health Education Research 2015 Jun; 30(3):422-435. 2015.

22) Rowley TW, Lenz EK, Swartz AM, Miller NE, Maeda H, Strath SJ. Efficacy of an individually tailored, internet-mediated physical activity intervention in older adults: a randomized controlled trial. Journal of Applied Gerontology 2017 Oct 1:Epub ahead of print. 2017.

23) Higgins JP, Altman DG, Gotzsche PC, Juni P, Moher D, Oxman AD, et al. The Cochrane Collaboration's tool for assessing risk of bias in randomised trials. BMJ. 2011; 343:d5928.

24) Kim BY, Lee J. Smart Devices for Older Adults Managing Chronic Disease: A Scoping Review. Jmir Mhealth and Uhealth. 2017; 5(5).

25) Moher D, Liberati A, Tetzlaff J, Altman DG, Group P. Preferred reporting items for systematic reviews and meta-analyses: the PRISMA statement. J Clin Epidemiol. 2009; 62(10):1006-12.

26) Muellmann S, Forberger S, Mollers T, Broring E, Zeeb H, Pischke CR. Effectiveness of eHealth interventions for the promotion of physical activity in older adults: A systematic review. Prev Med. 2018; 108:93-110.

27) World Health Organization. Agenda item 12.4. Digital health resolution. In: Seventy-first World Health Assembly. Geneva; 2018.

28) Ramprasad C, Tamariz L, Garcia-Barcena Y, Palacio A. The use of tablet technology by elderly in health care settings-is it effective and satisfying? A systematic review and meta analysis. Journal of General Internal Medicine. 2015; 2):S75-S6.

29) Schafer AGM, Zalpour C, von Piekartz H, Hall TM, Paelke V. The Efficacy of Electronic Health-Supported Home Exercise Interventions for Patients With Osteoarthritis of the Knee: Systematic Review. J Med Internet Res. 2018; 20(4):e152.

30) Hawley H, Tacconi C, Mellone S, Martinez E, Easdon A, Yang F, et. al. Can smartphone Technology be used to support an Effective Home Exercise intervention to prevent falls amongst community dwelling older adults? The TOGETHER feasibility RCT study protocol 18 Sep 2019, (Accepted/In press) In :BMJ Open 


\section{PRISMA 2009 Flow Diagram}
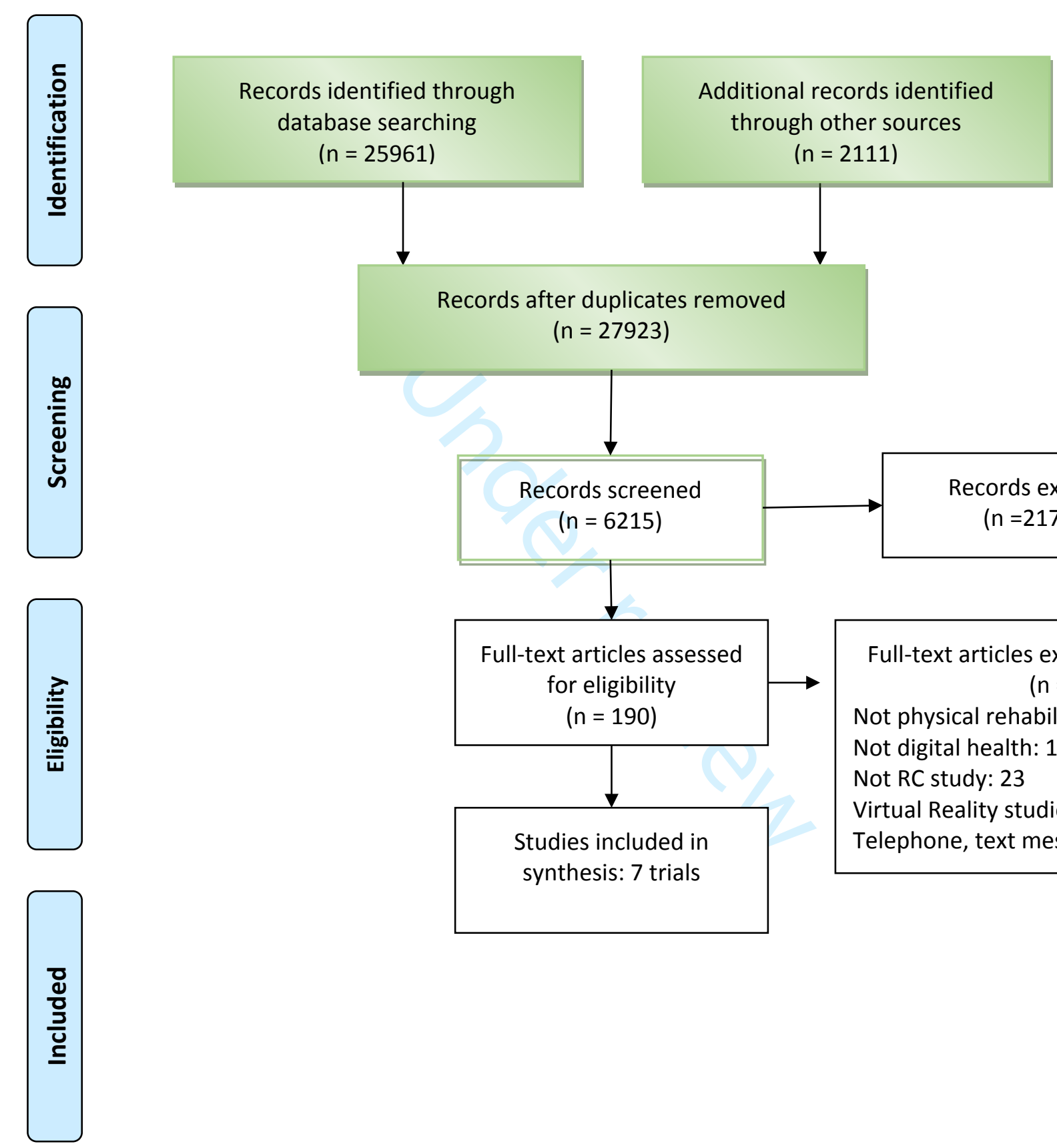

$$
\begin{aligned}
& \text { Records after duplicates removed } \\
& \qquad(\mathrm{n}=27923)
\end{aligned}
$$
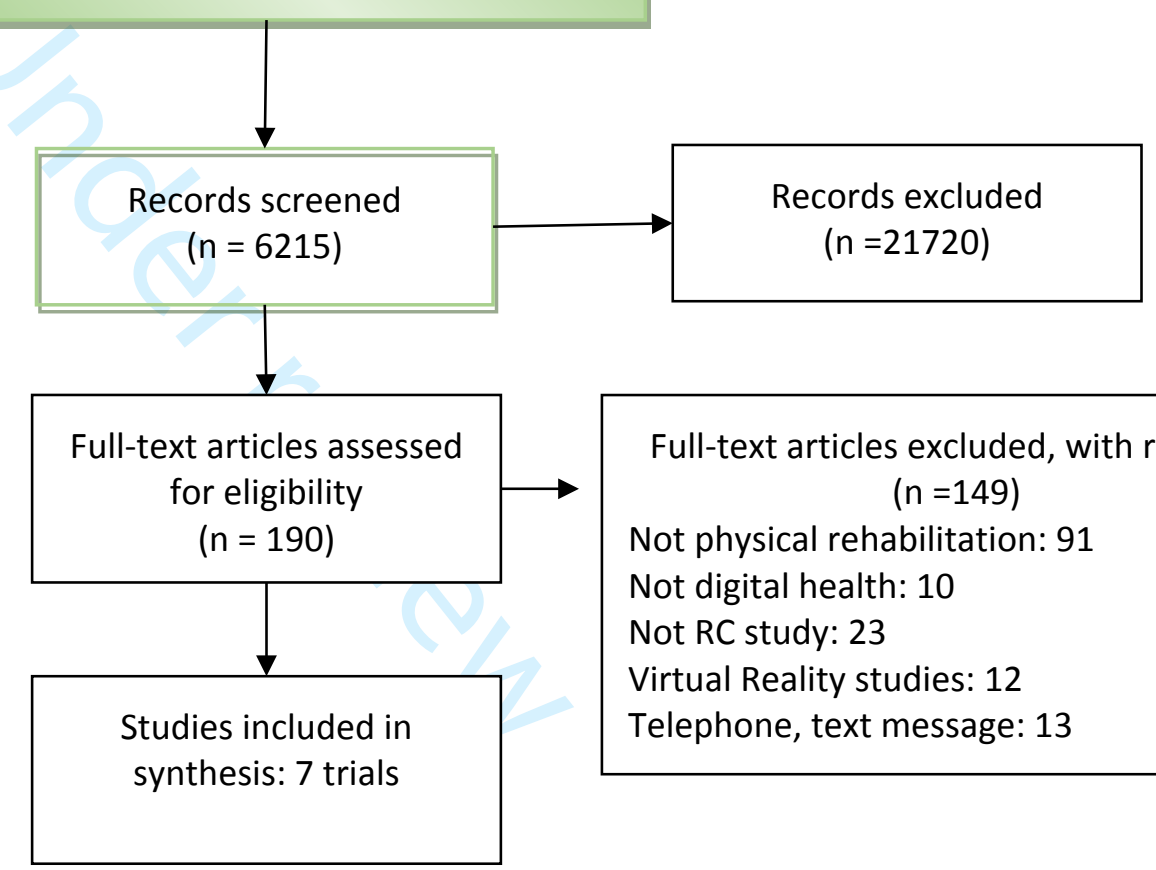

Full-text articles excluded, with reasons

$$
\text { ( } n=149 \text { ) }
$$

Not physical rehabilitation: 91

Not digital health: 10

Not RC study: 23

Virtual Reality studies: 12

Telephone, text message: 13

Figure 1 From: Moher D, Liberati A, Tetzlaff J, Altman DG, The PRISMA Group (2009). Preferred Reporting Items for Systematic Reviews and Meta-
Analyses: The PRISMA Statement. PLoS Med 6(7): e1000097. doi:10.1371/journal.pmed1000097 
From: Moher D, Liberati A, Tetzlaff J, Altman DG, The PRISMA Group (2009). Preferred Reporting Items for Systematic Reviews and MetaAnalyses: The PRISMA Statement. PLoS Med 6(7): e1000097. doi:10.1371/journal.pmed1000097

\section{For more information, visit www.prisma-statement.org.}

ScholarOne, 375 Greenbrier Drive, Charlottesville, VA, 22901 
Table 1. Characteristics of the included trials.

\begin{tabular}{|c|c|c|c|c|c|c|}
\hline $\begin{array}{l}\text { Author \& Year } \\
\text { Country }\end{array}$ & $\begin{array}{l}\text { Randomised }(\mathrm{N}) \\
\text { Mean age in years } \\
\text { Gender \% }\end{array}$ & Key eligibility criteria & $\begin{array}{l}\text { Outcomes relevant } \\
\text { to the review }\end{array}$ & Control intervention & Digital rehabilitation intervention & Duration \\
\hline $\begin{array}{l}\text { Irvine } 2013[10] \\
\text { United States }\end{array}$ & $\begin{array}{c}405 \\
60.3 \text { years } \\
69.4 \% \text { females }\end{array}$ & $\begin{array}{l}\text { Inclusion: Aged above } 55 \text { years with } \\
\text { no more } 60 \mathrm{~min} / \text { week moderate } \\
\text { exercise }\end{array}$ & $\begin{array}{l}\text { Physical activity; } \\
\text { Quality of life; User } \\
\text { satisfaction; Barriers to } \\
\text { exercise }\end{array}$ & No intervention & $\begin{array}{l}\text { Active After } 55 \text { : Personalised physical } \\
\text { activity programme. } 11 \text { weekly sessions, } 10 \text { - } \\
15 \text { minutes each. }\end{array}$ & 3 months \\
\hline $\begin{array}{l}\text { Bickmore, } 2013[17] \\
\text { United States }\end{array}$ & $\begin{array}{c}263 \\
71.3 \text { years } \\
61.2 \% \text { females }\end{array}$ & $\begin{array}{l}\text { Inclusion: Aged } 65 \text { year and over, } \\
\text { inactive, stable medical condition } \\
\text { Exclusion: Cognitive and depressive } \\
\text { symptoms, high risk of fall risk. }\end{array}$ & $\begin{array}{l}\text { Physical activity; } \\
\text { Adverse events; } \\
\text { Treatment satisfaction }\end{array}$ & $\begin{array}{l}\text { Pedometers were } \\
\text { worn and steps were } \\
\text { monitored. }\end{array}$ & $\begin{array}{l}\text { Tablet computers connected with } \\
\text { pedometers to deliver an embodied } \\
\text { conversational agent (animated characters) } \\
\text { based physical activity intervention. }\end{array}$ & 2 months \\
\hline $\begin{array}{l}\text { Wijsman } 2013[18] \& \\
\text { Broekhuizen } 2016[19] \\
\text { Netherlands }\end{array}$ & $\begin{array}{c}235 \\
65 \text { years } \\
41 \% \text { females }\end{array}$ & $\begin{array}{l}\text { Inclusion: Inactive, no Diabetes, no } \\
\text { glucose-lowering medication, no } \\
\text { disability impeding physical activity. }\end{array}$ & $\begin{array}{l}\text { Physical Activity; } \\
\text { Quality of life }\end{array}$ & Waiting list & $\begin{array}{l}\text { Direct Life physical activity programme: } \\
\text { Included an accelerometer-based activity } \\
\text { monitor, a website, and a personal-coach to } \\
\text { monitor and provide tips via email. }\end{array}$ & 3 months \\
\hline $\begin{array}{l}\text { Geraghty } 2017[20] \\
\text { United Kingdom }\end{array}$ & $\begin{array}{c}296 \\
67 \text { years } \\
67 \% \text { females }\end{array}$ & $\begin{array}{l}\text { Inclusion: } 50 \text { years and above, } \\
\text { dizziness over } 2 \text { years, have internet } \\
\text { access } \\
\text { Exclusion: Medical } \\
\text { contraindications, e.g. serious co- } \\
\text { morbidity }\end{array}$ & $\begin{array}{l}\text { Dizziness related } \\
\text { disability; Depression }\end{array}$ & $\begin{array}{l}\text { Usual care - } \\
\text { education, } \\
\text { reassurance, } \\
\text { medication for } \\
\text { nausea. }\end{array}$ & $\begin{array}{l}\text { Balance retraining: Fully automated online } \\
\text { programme. } 6 \text { sessions with vestibular } \\
\text { exercises and coping strategies. }\end{array}$ & 1.5 months \\
\hline $\begin{array}{l}\text { Gschwind } 2015 \text { [21] } \\
\text { Australia }\end{array}$ & $\begin{array}{c}153 \\
74.7 \text { years } \\
61.2 \% \text { females }\end{array}$ & $\begin{array}{l}\text { Inclusion: Aged } 65 \text { years and above, } \\
\text { able to walk } 20 \text { metres unaided and } \\
\text { watch television from } 3 \text { metres. } \\
\text { Exclusion: Language problems, } \\
\text { cognitive impairment, medical } \\
\text { conditions limiting participation. }\end{array}$ & $\begin{array}{l}\text { General health; } \\
\text { Depression; Balance ; } \\
\text { Adverse events; } \\
\text { Adherence; Falls } \\
\text { efficacy ; User } \\
\text { experience }\end{array}$ & $\begin{array}{l}\text { Evidence-based } \\
\text { educational booklet } \\
\text { on healthy lifestyle } \\
\text { and fall prevention. }\end{array}$ & $\begin{array}{l}\text { iStoppFalls: An Information and } \\
\text { Communication based system for assessing } \\
\text { fall risks and preventing falls in older } \\
\text { people. }\end{array}$ & 4 months \\
\hline $\begin{array}{l}\text { Mouton 2015 } \\
\text { Belgium [22] }\end{array}$ & $\begin{array}{c}102 \\
\text { Intervention: } 61.2 \text { years } \\
\text { Control: } 66.1 \text { years } \\
\\
\text { Intervention: } 39.6 \% \text { males } \\
\text { Control: } 38.3 \% \text { males }\end{array}$ & $\begin{array}{l}\text { Inclusion: } 50 \text { years and above, } \\
\text { French language, access to Internet. }\end{array}$ & $\begin{array}{l}\text { Physical activity; User } \\
\text { Satisfaction }\end{array}$ & No intervention & $\begin{array}{l}\text { Move More: The web-based programme } \\
\text { covered benefits of physical activity, success } \\
\text { stories, exercises, overcoming barriers, and } \\
\text { tailored feedback. }\end{array}$ & 3 months \\
\hline $\begin{array}{l}\text { Rowley } 2017 \text { [23] } \\
\text { United States }\end{array}$ & $\begin{array}{c}108 \\
\text { Intervention: } 67.4 \text { years } \\
\text { Control: } 66.1 \text { years } \\
\\
\text { Intervention: } 81.3 \% \text { females } \\
\text { Control: } 78.6 \% \text { females }\end{array}$ & $\begin{array}{l}\text { Inclusion: Inactive adults, no } \\
\text { limitations to walking, access to } \\
\text { computer. }\end{array}$ & Physical activity & No intervention & $\begin{array}{l}\text { Tailored, internet pedometer-based } \\
\text { programme to reach } 10000 \text { steps per day and } \\
\text { maintain afterward. }\end{array}$ & 3 months \\
\hline
\end{tabular}


Table 2. The Behavioural Intervention Technology (BIT) Model mapped to digital rehabilitation interventions in older adults.

\begin{tabular}{|c|c|c|c|c|c|}
\hline $\begin{array}{c}\text { Digital rehabilitation } \\
\text { intervention }\end{array}$ & Aims & Behavioural change strategies & Elements & Characteristics & Workflow \\
\hline $\begin{array}{l}\text { Active After } 55 \text { : Internet } \\
\text { based physical activity } \\
\text { programme [10] }\end{array}$ & $\begin{array}{l}\text { To promote function and } \\
\text { mobility in older adults. Adopts } \\
\text { a self-tailored approach based } \\
\text { on theory of planned behaviour. }\end{array}$ & $\begin{array}{l}\text { Goal setting; Self-tailored exercise } \\
\text { planning/Ownership; Barrier } \\
\text { identification; Review of progress; } \\
\text { Knowledge on exercise benefits; } \\
\text { Encouragement }\end{array}$ & $\begin{array}{l}\text { Success stories; Library for } \\
\text { more articles; Safety tips; } \\
\text { Disease specific } \\
\text { recommendations }\end{array}$ & $\begin{array}{l}\text { Medium: A narrator and personal coach } \\
\text { presented text and video messages } \\
\text { Complexity: Grade } 6-8 \text { reading level; } \\
\text { Bullet text points; New exercises added } \\
\text { Aesthetics: Not reported. } \\
\text { Personalisation: Self prescribed activities }\end{array}$ & $\begin{array}{l}\text { The website was in browser format and } \\
\text { participants navigate the website freely in } \\
\text { non-linear pathway. }\end{array}$ \\
\hline $\begin{array}{l}\text { A computer and embodied } \\
\text { conversational agent based } \\
\text { physical activity programme } \\
\text { [17]. }\end{array}$ & $\begin{array}{l}\text { To promote health behaviour } \\
\text { change of older adults with low } \\
\text { education and health literacy } \\
\text { levels. }\end{array}$ & $\begin{array}{l}\text { Goal setting; Review of progress; } \\
\text { Positive reinforcement; Barrier } \\
\text { identification; Problem solving } \\
\text { Self-monitoring. }\end{array}$ & $\begin{array}{l}\text { Simulated face-to-face } \\
\text { encounters with an embodied } \\
\text { conversational agent (Virtual } \\
\text { coach); Animated characters } \\
\text { demonstrating exercises; Step } \\
\text { count charts; Daily exercise tips. }\end{array}$ & $\begin{array}{l}\text { Medium: Interactive conversations with } \\
\text { agent by choosing replies from multiple } \\
\text { options; Images; Exercise demos. } \\
\text { Complexity: Not reported } \\
\text { Aesthetics: Intuitive and acceptable } \\
\text { Personalisation: Self-monitoring charts to } \\
\text { track step counts. }\end{array}$ & $\begin{array}{l}\text { Participants were given touch-screen tablet } \\
\text { computers and taught how to use the } \\
\text { conversational agent system and have daily } \\
\text { conversations for two months. At two } \\
\text { months, they were shown how to use a Kiosk } \\
\text { computer (had same ECA conversations) } \\
\text { when waiting for the scheduled clinical } \\
\text { appointments. }\end{array}$ \\
\hline $\begin{array}{l}\text { An Internet based interactive } \\
\text { physical activity programme } \\
{[18,19] .}\end{array}$ & $\begin{array}{l}\text { To increase daily physical } \\
\text { activity. Based on the stages of } \\
\text { change and I-Change Model. }\end{array}$ & $\begin{array}{l}\text { Goal setting; Regular feedback; } \\
\text { Continuous contact with digital } \\
\text { coaches. }\end{array}$ & $\begin{array}{l}\text { Accelerometer-based activity } \\
\text { monitor; A personal-website } \\
\text { A personal e-coach }\end{array}$ & $\begin{array}{l}\text { Medium: Interactive website; Coaches } \\
\text { provided updates and advice via email. } \\
\text { Complexity: Not reported } \\
\text { Aesthetics: Not reported. } \\
\text { Personalisation: Not reported. }\end{array}$ & $\begin{array}{l}\text { Participants wore the activity monitor } \\
\text { continuously through the day and } \\
\text { personalised physical activity targets were } \\
\text { set. }\end{array}$ \\
\hline $\begin{array}{l}\text { A fully automated online } \\
\text { balance retraining programme } \\
\text { [20]. }\end{array}$ & $\begin{array}{l}\text { To facilitate central nervous } \\
\text { system compensation } \\
\text { mechanisms with specific } \\
\text { vestibular rehabilitation } \\
\text { exercises. }\end{array}$ & $\begin{array}{l}\text { Goal setting; Tailored feedback; } \\
\text { Education on dizziness, exercises } \\
\text { and behavioural coping strategies; } \\
\text { Cognitive restructuring; Problem } \\
\text { solving. }\end{array}$ & $\begin{array}{l}\text { Video demonstrations of } \\
\text { exercises; Success stories; } \\
\text { Email reminders. }\end{array}$ & $\begin{array}{l}\text { Medium: Text and exercise videos } \\
\text { Complexity: Content in lay language; large } \\
\text { font size; bullet points } \\
\text { Aesthetics: Simple look and design. } \\
\text { Personalisation: Feedback and exercise } \\
\text { prescription based on symptoms. }\end{array}$ & $\begin{array}{l}\text { Participants logged in each week over } 6 \\
\text { sessions. They undertook automatic tailored } \\
\text { exercises based on their symptoms and } \\
\text { balance capabilities and received symptom } \\
\text { specific feedback each week. }\end{array}$ \\
\hline $\begin{array}{l}\text { iStoppFalls: An Information } \\
\text { and Communication based } \\
\text { system to predict and prevent } \\
\text { falls [21]. }\end{array}$ & $\begin{array}{l}\text { To predict falls risk and provide } \\
\text { tailored exercise programme for } \\
\text { balance and feedback. }\end{array}$ & $\begin{array}{l}\text { Education on falls prevention } \\
\text { strategies and exercise safety; } \\
\text { Feedback; Self-monitoring; Social } \\
\text { support (integrated social media } \\
\text { platform to interact with others). }\end{array}$ & $\begin{array}{l}\text { Exergames for balance, muscle } \\
\text { strength and Fall risk } \\
\text { assessment; Exercise activity } \\
\text { tracker; Monthly falls diary; } \\
\text { Printed guidelines on exercise } \\
\text { safety. }\end{array}$ & $\begin{array}{l}\text { Medium: Exer-games } \\
\text { Complexity: Simple to Dual-tasking for } \\
\text { balance; Increased repetitions, sets, } \\
\text { difficulty level for strength exercises. } \\
\text { Aesthetics: Not reported. } \\
\text { Personalisation: Real-time feedback }\end{array}$ & $\begin{array}{l}\text { Participants were provided with a computer, } \\
\text { a set top box, and a Microsoft Kinect sensor, } \\
\text { a Senior Mobility Monitor to monitor } \\
\text { mobility and performance, and Android } \\
\text { tablet to monitor the results. Participants } \\
\text { interacted with the virtual Avatar to do the } \\
\text { exergames. }\end{array}$ \\
\hline $\begin{array}{l}\text { Move More: Web-based } \\
\text { physical activity programme } \\
\text { [22]. }\end{array}$ & $\begin{array}{l}\text { To improve self-efficacy and } \\
\text { physical activity behaviours. } \\
\text { Based on trans-theoretical } \\
\text { model of health behaviour } \\
\text { change and ecological model. }\end{array}$ & $\begin{array}{l}\text { Goal setting; Education on } \\
\text { benefits of physical activity; } \\
\text { Overcoming barriers; Action } \\
\text { planning; Feedback; Social } \\
\text { support. }\end{array}$ & $\begin{array}{l}\text { Success stories; Additional } \\
\text { links; Tips for physical activity; } \\
\text { Online forum; Local physical } \\
\text { activity opportunities. }\end{array}$ & $\begin{array}{l}\text { Medium: Text, Links } \\
\text { Complexity: Not reported } \\
\text { Aesthetics: Not reported. } \\
\text { Personalisation: Physical activity journal, } \\
\text { automatic tailored monthly feedback. }\end{array}$ & $\begin{array}{l}\text { The website was in browser format and } \\
\text { participants navigated the website in non- } \\
\text { linear pathway. }\end{array}$ \\
\hline $\begin{array}{l}\text { An Internet based physical } \\
\text { activity programme [23]. }\end{array}$ & $\begin{array}{l}\text { To understand the benefits of } \\
\text { physical activity and to increase } \\
\text { awareness of current physical } \\
\text { activity level. }\end{array}$ & $\begin{array}{l}\text { Goal setting; Education; Self- } \\
\text { regulation; Feedback; Rewarding; } \\
\text { Barrier identification; Ask the } \\
\text { expert; Social support. }\end{array}$ & $\begin{array}{l}\text { Graphical feedback of daily } \\
\text { steps; Ask the expert; discussion } \\
\text { forum; Motivational messages; } \\
\text { Links to other physical activity } \\
\text { sites. }\end{array}$ & $\begin{array}{l}\text { Medium: Interactive messages } \\
\text { Complexity: Not reported } \\
\text { Aesthetics: Not reported. } \\
\text { Personalisation: Tailored messaging }\end{array}$ & $\begin{array}{l}\text { Participants logged in once a week. To begin } \\
\text { with, education and self-awareness of } \\
\text { physical activity were provided. Participants } \\
\text { then set goals to increase weekly steps by } \\
10 \% \text {. }\end{array}$ \\
\hline
\end{tabular}


Table 3. Risk of bias assessments

\begin{tabular}{|c|c|c|c|c|c|c|c|}
\hline Trials & $\begin{array}{c}\text { Random } \\
\text { generation }\end{array}$ & $\begin{array}{c}\text { Allocation } \\
\text { concealment }\end{array}$ & $\begin{array}{c}\text { Blinding of } \\
\text { participants }\end{array}$ & $\begin{array}{c}\text { Blinding of } \\
\text { personnel }\end{array}$ & $\begin{array}{l}\text { Blinding of } \\
\text { assessment }\end{array}$ & $\begin{array}{c}\text { Incomplete } \\
\text { outcome data }\end{array}$ & $\begin{array}{l}\text { Selective } \\
\text { bias }\end{array}$ \\
\hline Bickmore 2013 [17] & Unclear & Unclear & High & High & Low & Low & Low \\
\hline Geraghty 2017 [20] & Low & Low & Unclear & Low & Low & Low & Low \\
\hline Gschwind 2015 [21] & Low & Unclear & High & High & Low & Low & Low \\
\hline Irvine 2013 [10] & Unclear & Unclear & High & Low & Low & Low & Low \\
\hline Mouton 2015 [22] & Low & Unclear & Unclear & Unclear & Low & Low & Low \\
\hline Rowley 2017 [23] & Unclear & Unclear & Unclear & Unclear & High & Low & Low \\
\hline $\begin{array}{l}\text { Wijsman } 2013 \text { [18] \& } \\
\text { Broekhuizen } 2016 \text { [19] }\end{array}$ & Low & Unclear & High & High & High & Low & Low \\
\hline
\end{tabular}


Table 4. Effects of digital rehabilitation interventions on physical activity in older adults.

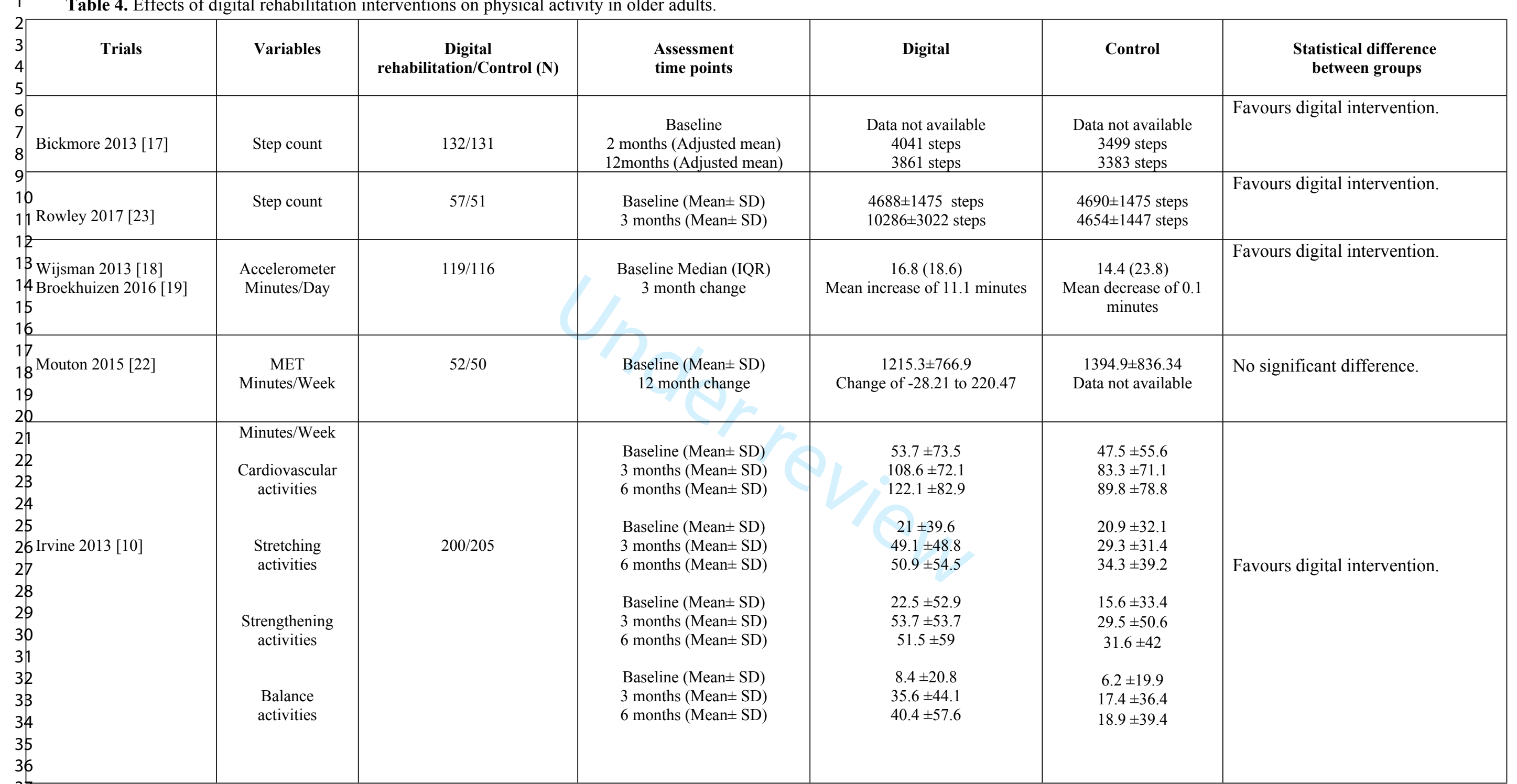

IQR: Inter-quartile range; MET: Metabolic Equivalent Task; SD: Standard Deviation. 
Table 5. Effects of digital rehabilitation interventions on quality of life, vertigo, and risk of falls in older adults.

\begin{tabular}{|c|c|c|c|c|c|c|c|}
\hline Trials & Variables & $\begin{array}{c}\text { Digital } \\
\text { rehabilitation/Control } \\
(\mathbf{N})\end{array}$ & \multicolumn{2}{|c|}{ Assessment time points } & $\begin{array}{c}\text { Digital } \\
\text { rehabilitation }\end{array}$ & Control & $\begin{array}{l}\text { Statistical difference } \\
\text { between groups }\end{array}$ \\
\hline Gschwind 2015 [21] & EQ-5D & $78 / 75$ & \multicolumn{2}{|c|}{$\begin{array}{l}\text { Baseline }(\text { Mean } \pm \text { SD) } \\
3 \text { months }(\text { Mean } \pm \text { SD) }\end{array}$} & $\begin{array}{l}0.86 \pm 0.11 \\
0.86 \pm 0.15\end{array}$ & $\begin{array}{l}0.86 \pm 0.13 \\
0.87 \pm 0.13\end{array}$ & No significant difference. \\
\hline \multirow[t]{2}{*}{ Irvine 2013 [10] } & \multirow[t]{2}{*}{ SF-12 } & \multirow[t]{2}{*}{$200 / 205$} & \multicolumn{2}{|c|}{$\begin{array}{l}\text { SF-12 Physical Log base } 10 \\
\text { transformation } \\
\text { Baseline } \\
3 \text { months } \\
6 \text { months }\end{array}$} & $\begin{aligned}-0.01 & \pm 0.76 \\
0.03 & \pm 0.66 \\
0.04 & \pm 0.66\end{aligned}$ & $\begin{array}{c}0 \pm 0.82 \\
-0.07 \pm 0.87 \\
-0.07 \pm 0.84\end{array}$ & Favours digital intervention. \\
\hline & & & \multicolumn{2}{|c|}{$\begin{array}{l}\text { SF-12 Mental Log base } 10 \text { transformation } \\
\text { Baseline } \\
3 \text { months } \\
6 \text { months }\end{array}$} & $\begin{array}{c}0.7 \pm 0.8 \\
0.88 \pm 0.7 \\
0.86 \pm 0.72 \\
\end{array}$ & $\begin{array}{c}0.8 \pm 0.8 \\
0.71 \pm 0.8 \\
0.7 \pm 0.84 \\
\end{array}$ & Favours digital intervention. \\
\hline \multirow{3}{*}{$\begin{array}{l}\text { Broekhuizen } 2016 \\
\text { [19] }\end{array}$} & \multirow{3}{*}{ RAND-36 } & \multirow{3}{*}{$119 / 116$} & Physical function & $\begin{array}{l}\text { Baseline (Mean } \pm \text { SD) } \\
3 \text { month-change }\end{array}$ & $\begin{array}{c}83.40 \pm 14.98 \\
1.84(1.16)\end{array}$ & $\begin{array}{l}84.61 \pm 15.5 \\
0.95(1.01)\end{array}$ & No significant difference. \\
\hline & & & Mental health & $\begin{array}{l}\text { Baseline }(\text { Mean } \pm \text { SD) } \\
3 \text { month-change }\end{array}$ & $\begin{array}{l}77.24 \pm 15.52 \\
2.52(0.83)\end{array}$ & $\begin{array}{l}77.31 \pm 15.58 \\
-0.72(1.19)\end{array}$ & Favours digital intervention. \\
\hline & & & Total RAND-36 & $\begin{array}{l}\text { Baseline (Mean } \pm \text { SD) } \\
3 \text { month-change }\end{array}$ & $\begin{array}{c}630.86 \pm 120.12 \\
6.28(8.13)\end{array}$ & $\begin{array}{c}639.68 \pm 118.64 \\
-0.89(7.57)\end{array}$ & No significant difference. \\
\hline Geragty 2017 [20] & $\begin{array}{l}\text { VS-SF } \\
\text { total score }\end{array}$ & $160 / 136$ & \multicolumn{2}{|c|}{$\begin{array}{l}\text { Baseline Median (IQR) } \\
3 \text { months Median (IQR) } \\
6 \text { months Median (IQR) }\end{array}$} & $\begin{array}{l}14(8-22) \\
6(3-12) \\
6(3-14)\end{array}$ & $\begin{array}{l}13(7-22) \\
9(5-15) \\
7(4-17)\end{array}$ & Favours digital intervention. \\
\hline Gschwind 2015 [21] & PPA & $78 / 75$ & \multicolumn{2}{|c|}{$\begin{array}{l}\text { Baseline }(\text { Mean } \pm \text { SD) } \\
3 \text { months }(\text { Mean } \pm \text { SD) }\end{array}$} & $\begin{array}{l}0.62 \pm 0.89 \\
0.41 \pm 0.95\end{array}$ & $\begin{array}{l}0.55 \pm 0.90 \\
0.39 \pm 0.80\end{array}$ & Favours digital intervention. \\
\hline
\end{tabular}

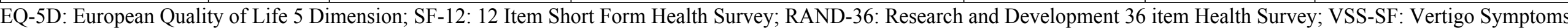
Scale-Short Form; PPA: Physiological Profile Assessment; IQR: Inter-quartile range; SD: Standard deviation. 
Table 6. The quality of evidence for the effectiveness of digital rehabilitation interventions in older adults

5

$\oint$

$\$$

\$ Physical activity

$10_{1}$ Short-term

11

12

13 Short-term

14

15

16 Medium-term

18

19

20 Long-term

21

22 Long-term

23

24

\section{Quality of life (QoL)}

26

27 QoL Physical

28 Short-term

29

30 QoL Mental

31 Short-term

32

33

34 QoL (Total score)

35 Short-term

36

36

37 QoL (Total score)

38 Short-term

39

40

41QoL (Physical \& Mental)

42 Medium-term

43

\section{Vertigo symptoms}

45

46 Short \& Medium-term

\section{Falls}

${ }_{4}$ Short-term

49

50

51

${ }^{1}$ Downgraded to one level for risk of bias.

${ }^{2}$ Downgraded to three levels for risk of bias and being a single trial with $<400$ participants.

${ }^{3}$ Downgraded to one level for risk of bias.

${ }^{4}$ Downgraded to three levels for risk of bias, inconsistent results, and indirectness of evidence.

${ }^{5}$ Downgraded to two levels for risk of bias and indirectness of evidence. 


\section{Supplementary File 1}

Search Strategies (06/11/18)

\section{Database: Medline (Ovid MEDLINE ${ }^{\circledR}$ Epub Ahead of Print, In-Process \& Other Non-Indexed} Citations, Ovid MEDLINE ${ }^{\circledR}$ Daily and Ovid MEDLINE ${ }^{\circledR}$ ) 1946 to present

Search Strategy:

1 exp aged/ or middle aged/ (4673065)

2 exp Aging/ (231158)

3 elder*.ti,ab. (234110)

4 senior*.ti,ab. (35909)

5 "old* age*".ti,ab. (66736)

6 "old* person*".ti,ab. (11433)

7 "old* adult*".ti,ab. (66327)

8 "old* people*".ti,ab. (27992)

9 "ageing person*".ti,ab. (31)

10 "aging person*".ti,ab. (166)

11 "ageing adult*".ti,ab. (58)

12 "aging adult*".ti,ab. (546)

13 geriatric*.ti,ab. (42239)

14 pensioner*.ti,ab. (934)

15 frail*.ti,ab. (16859)

16 exp Veterans/ (14508)

17 veteran*.ti,ab. (31482)

18 "older population*".ti,ab. (5409)

191 or 2 or 3 or 4 or 5 or 6 or 7 or 8 or 9 or 10 or 11 or 12 or 13 or 14 or 15 or 16 or 17 or 18 (4954039)

20 exp Internet/ (70681)

21 exp Telemedicine/ (23708)

22 exp Computers/ (74831)

23 Multimedia/ (1799)

24 exp Cell Phone/ (8998)

25 Mobile Applications/ (3491)

26 "e-health*".ti,ab. (1868)

27 ehealth*.ti,ab. (1903)

28 "m-health*".ti,ab. (306)

29 "mobile health*".ti,ab. (2239)

30 mhealth*.ti,ab. (1874)

31 compute*.ti,ab. (590929)

32 web*.ti,ab. (126521)

33 online.ti,ab. (87199)

34 internet*.ti,ab. (43887)

35 ("technology based" or technologybased or technology-based).ti,ab. (2577)

36 virtual*.ti,ab. (114260) 
37 digital*.ti,ab. (121337)

38 ("social media" or twitter or tweet* or facebook or blog* or microblog*).ti,ab. (10805)

39 Electronic Mail/ (2460)

40 (email* or e-mail* or "e mail*").ti,ab. (13581)

41 (telerehabilitation or tele-rehabilitation or "tele rehabilitation").ti,ab. (614)

42 (telemedicine or tele-medicine).ti,ab. (8754)

43 (mobile adj2 (phone* or telephon*)).ti,ab. (6934)

44 (cell adj2 (phone* or telephon*)).ti,ab. (2173)

45 smartphone*.ti,ab. (6782)

46 "smart phone*".ti,ab. (877)

47 "text messag*".ti,ab. (3025)

48 (txt or pxt or mms or sms).ti,ab. (9491)

49 iphone*.ti,ab. (684)

50 "voice messag*".ti,ab. (88)

51 nokia.ti,ab. (90)

52 blackberry.ti,ab. (554)

53 symbian.ti,ab. (9)

54 (windows adj3 (mobile* or phone*)).ti,ab. (49)

55 android.ti,ab. (1884)

56 ipad*.ti,ab. (1172)

57 (app* adj3 (smartphone* or smart-phone or mobile* or phone*)).ti,ab. (7751)

58 skype*.ti,ab. (289)

59 "CD rom*".ti,ab. (1258)

60 cdrom*.ti,ab. (23)

6120 or 21 or 22 or 23 or 24 or 25 or 26 or 27 or 28 or 29 or 30 or 31 or 32 or 33 or 34 or 35 or 36 or 37 or 38 or 39 or 40 or 41 or 42 or 43 or 44 or 45 or 46 or 47 or 48 or 49 or 50 or 51 or 52 or 53 or 54 or 55 or 56 or 57 or 58 or 59 or 60 (1117560)

62 exp Chronic Disease/ (251626)

63 exp neoplasms/ or exp musculoskeletal diseases/ or exp respiratory tract diseases/ or exp nervous system diseases/ or exp cardiovascular diseases/ or exp endocrine system diseases/ (8521078)

64 Accidental Falls/ (21350)

65 exp Fractures, Bone/ (171923)

66 chronic*.ti,ab. (1093813)

67 prolong*.ti,ab. (346981)

68 "long term*".ti,ab. (719228)

69 longterm*.ti,ab. (6226)

70 musculoskeletal*.ti,ab. (42880)

71 "musculo-skeletal*".ti,ab. (1209)

72 rheumat*.ti,ab. (167090)

73 "physical disease*".ti,ab. (906)

74 balance*.ti,ab. (249107)

75 (fall or falls or falling or fell).ti,ab. (208953)

76 stroke.ti,ab. (209265) 
77 "cerebrovascular accident*".ti,ab. (6294)

78 parkinson*.ti,ab. (103281)

79 (cancer* or metasta* or tumor* or tumour* or carcinom* or malignan* or neoplasm*).ti,ab. (2962744)

80 diabet*.ti,ab. (561053)

81 neurological*.ti,ab. (201125)

82 fracture*.ti,ab. (230590)

83 (bone* adj3 (break* or broken)).ti,ab. (1112)

8462 or 63 or 64 or 65 or 66 or 67 or 68 or 69 or 70 or 71 or 72 or 73 or 74 or 75 or 76 or 77 or 78 or 79 or 80 or 81 or 82 or 83 (11026602)

85 exp Rehabilitation/ (279370)

86 exp Exercise/ (171234)

87 rehabilit*.ti,ab. (147504)

88 exercise*.ti,ab. (261377)

89 (physical* adj2 activ*).ti,ab. (99838)

90 activit*.ti,ab. (2808092)

91 mobilit*.ti,ab. (130746)

92 exp Physical Therapy Modalities/ (139250)

93 physio*.ti,ab. (680446)

94 "physical therap*".ti,ab. (19690)

95 balance*.ti,ab. (249107)

96 movement*.ti,ab. (283491)

97 function*.ti,ab. (3293197)

98 intervention*.ti,ab. (847363)

99 technolog*.ti,ab. (395870)

10085 or 86 or 87 or 88 or 89 or 90 or 91 or 92 or 93 or 94 or 95 or 96 or 97 or 98 or 99 (7507059)

101 ((("semi-structured" or semistructured or unstructured or informal or "in-depth" or indepth or "face-to-face" or structured or guide) adj3 (interview* or discussion* or questionnaire*)) or (focus group* or qualitative or ethnograph* or fieldwork or "field work" or "key informant")).ti,ab. or interviews as topic/ or focus groups/ or narration/ or qualitative research/ (336174)

102 randomized controlled trial.pt. (470801)

103 controlled clinical trial.pt. (92735)

104 randomized.ab. (425865)

105 placebo.ab. (193019)

106 randomly.ab. (299961)

107 trial.ab. (443885)

108 groups.ab. (1849019)

109101 or 102 or 103 or 104 or 105 or 106 or 107 or 108 (2932974)

11019 and 61 and 84 and 100 and 109 (17202)

111110 (17202)

112 limit 111 to english language (16366) 


\section{Database: Embase 1974 to present}

Search Strategy:

1 exp aged/ (2684689)

2 middle aged/ (1278238)

3 exp aging/ (237398)

4 elder*.ti,ab. (325725)

5 senior*.ti,ab. (49042)

6 "old* age*".ti,ab. (91916)

7 "old* person*".ti,ab. (14415)

8 "old* adult*".ti,ab. (83055)

9 "old* people".ti,ab. (33494)

10 "ageing person*".ti,ab. (51)

11 "aging person*".ti,ab. (214)

12 "ageing adult*".ti,ab. (84)

13 "aging adult*".ti,ab. (690)

14 geriatric*.ti,ab. (65525)

15 pensioner*.ti,ab. (1182)

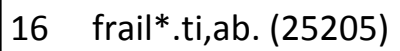

17 exp veteran/ (20718)

18 veteran*.ti,ab. (39688)

19 "older population*".ti,ab. (7484)

201 or 2 or 3 or 4 or 5 or 6 or 7 or 8 or 9 or 10 or 11 or 12 or 13 or 14 or 15 or 16 or 17 or 18 or 19 (3755970)

21 internet/ (99874)

22 exp telehealth/ (36338)

23 exp computer/ (126898)

24 multimedia/ (3488)

25 exp mobile phone/ (20727)

26 mobile application/ (6971)

27 "e-health*".ti,ab. (2481)

28 ehealth*.ti,ab. (2081)

29 "m-health*".ti,ab. (424)

30 "mobile health".ti,ab. (2240)

31 mhealth*.ti,ab. (1808)

32 compute*.ti,ab. (716158)

33 web*.ti,ab. (160335)

34 online.ti,ab. (123750)

35 internet*.ti,ab. (59032)

36 ("technology based" or technologybased or technology-based).ti,ab. (3254)

37 virtual*.ti,ab. (138170) $^{*}$ 
38 digital*.ti,ab. (148749)

39 ("social media" or twitter or tweet* or facebook or blog* or microblog*).ti,ab. (14781)

40 e-mail/ (17605)

41 (email* or e-mail* or "e mail*").ti,ab. (27146)

42 (telerehabilitation or tele-rehabilitation or "tele rehabilitation").ti,ab. (759)

43 (telemedicine or tele-medicine).ti,ab. (11686)

44 text messaging/ (3673)

45 (mobile adj2 (phone* or telephon*)).ti,ab. (8592)

46 (cell adj2 (phone* or telephon*)).ti,ab. (2962)

47 smartphone*.ti,ab. (8992)

48 "smart phone*".ti,ab. (1774)

49 "text messag*".ti,ab. (3949)

50 (txt or pxt or mms or sms).ti,ab. (12787)

51 iphone*.ti,ab. (1360)

52 "voice messag*".ti,ab. (125)

53 nokia.ti,ab. (119)

54 blackberry.ti,ab. (700)

55 symbian.ti,ab. (15)

56 (windows adj3 (mobile* or phone*)).ti,ab. (71)

57 android.ti,ab. (3012)

58 ipad*.ti,ab. (2449)

59 (app* adj3 (smartphone* or smart-phone or mobile* or phone*)).ti,ab. (10276)

60 skype*.ti,ab. (611)

61 "CD rom*".ti,ab. (1453)

62 cdrom*.ti,ab. (42)

6321 or 22 or 23 or 24 or 25 or 26 or 27 or 28 or 29 or 30 or 31 or 32 or 33 or 34 or 35 or 36 or 37 or 38 or 39 or 40 or 41 or 42 or 43 or 44 or 45 or 46 or 47 or 48 or 49 or 50 or 51 or 52 or 53 or 54 or 55 or 56 or 57 or 58 or 59 or 60 or 61 or 62 (1408669)

64 exp physical disease/ (17816871)

65 exp chronic disease/ (163610)

66 falling/ (36383)

67 exp fracture/ (255309)

68 chronic*.ti,ab. (1484638)

69 prolong*.ti,ab. (454207)

70 "long term*".ti,ab. (973815)

71 longterm*.ti,ab. (23551)

72 musculoskeletal*.ti,ab. (58735)

73 "musculo-skeletal*".ti,ab. (1755)

74 rheumat*.ti,ab. (238304)

75 "physical disease*".ti,ab. (1250)

76 balance*.ti,ab. (314131)

77 (fall or falls or falling or fell).ti,ab. (266941)

78 stroke.ti,ab. (329781)

79 "cerebrovascular accident*".ti,ab. (9339) 
80 parkinson*.ti,ab. (144706)

81 (cancer* or metasta* or tumor* or tumour* or carcinom* or malignan* or neoplasm*).ti,ab. (3829935)

82 diabet*.ti,ab. (819499)

83 neurological*.ti,ab. (294533)

84 fracture*.ti,ab. (267395)

85 (bone* adj3 (break* or broken)).ti,ab. (1490)

8664 or 65 or 66 or 67 or 68 or 69 or 70 or 71 or 72 or 73 or 74 or 75 or 76 or 77 or 78 or 79 or 80 or 81 or 82 or 83 or 84 or 85 (19033110)

87 exp rehabilitation/ (347360)

88 exp exercise/ (298442)

89 exp physical activity/ (359659)

90 rehabilit*.ti,ab. (204091)

91 exercise*.ti,ab. (342719)

92 (physical* adj2 activ*).ti,ab. (134778)

93 activit*.ti,ab. (3392656)

94 joint mobility/ (16459)

95 mobilit*.ti,ab. (148236)

96 exp physiotherapy practice/ or exp physiotherapy/ or exp home physiotherapy/ (76521)

97 physio*.ti,ab. (847766)

98 "physical therap*".ti,ab. (28349)

99 balance*.ti,ab. (314131)

100 movement*.ti,ab. (346621)

101 function*.ti,ab. (4016723)

102 intervention*.ti,ab. (1165427)

103 technolog*.ti,ab. (522827)

10487 or 88 or 89 or 90 or 91 or 92 or 93 or 94 or 95 or 96 or 97 or 98 or 99 or 100 or 101 or 102 or 103 (9298629)

105 (("semi-structured" or semistructured or unstructured or informal or "in-depth" or indepth or "face-to-face" or structured or guide) adj3 (interview* or discussion* or questionnaire*)).ti,ab. (134179)

106 (focus group* or qualitative or ethnograph* or fieldwork or "field work" or "key informant").ti,ab. (271972)

107 interviews as topic/ (126382)

108 focus groups/ (176773)

109 narration/ (13297)

110 qualitative research/ (57859)

111 random\$.tw. (1347860)

112 factorial\$.tw. (33668)

113 crossover\$.tw. (67891)

114 cross over\$.tw. (29790)

115 placebo\$.tw. (280363)

116 (doubl\$ adj blind\$).tw. (192329)

117 (singl\$ adj blind\$).tw. (21872) 


\begin{tabular}{|c|c|}
\hline 118 & assign\$.tw. (349128) \\
\hline 119 & allocat\$.tw. (132321) \\
\hline 120 & volunteer\$.tw. (237135) \\
\hline 121 & Crossover Procedure/ (57187) \\
\hline 122 & "double-blind procedure".tw. (1) \\
\hline 123 & Randomized Controlled Trial/ (521873) \\
\hline 124 & Single Blind Procedure/ (32981) \\
\hline $\begin{array}{l}125 \\
118\end{array}$ & $\begin{array}{l}105 \text { or } 106 \text { or } 107 \text { or } 108 \text { or } 109 \text { or } 110 \text { or } 111 \text { or } 112 \text { or } 113 \text { or } 114 \text { or } 115 \text { or } 116 \text { or } 117 \text { or } \\
119 \text { or } 120 \text { or } 121 \text { or } 122 \text { or } 123 \text { or } 124(2613231)\end{array}$ \\
\hline 126 & trial.ti,ab. (736974) \\
\hline 127 & 125 or $126(2902666)$ \\
\hline 128 & 20 and 63 and 86 and 104 and 127 (15823) \\
\hline 129 & $128(15823)$ \\
\hline 130 & limit 129 to english language (15361) \\
\hline
\end{tabular}

\section{Ebsco CINAHL}

\begin{tabular}{|c|c|c|c|c|}
\hline & Query & Limiters/Expanders & Last Run Via & $\begin{array}{c}\text { Results } \\
n\end{array}$ \\
\hline S123 & S19 AND S62 AND S90 AND S108 AND S121 & $\begin{array}{l}\text { Narrow by Language: } \\
\text { - english } \\
\text { Search modes - } \\
\text { Boolean/Phrase }\end{array}$ & $\begin{array}{l}\text { Interface - } \\
\text { EBSCOhost } \\
\text { Research } \\
\text { Databases } \\
\text { Search } \\
\text { Screen - } \\
\text { Advanced } \\
\text { Search } \\
\text { Database - } \\
\text { CINAHL }\end{array}$ & 3,623 \\
\hline S122 & S19 AND S62 AND S90 AND S108 AND S121 & $\begin{array}{l}\text { Search modes - } \\
\text { Boolean/Phrase }\end{array}$ & $\begin{array}{l}\text { Interface - } \\
\text { EBSCOhost } \\
\text { Research } \\
\text { Databases } \\
\text { Search } \\
\text { Screen - } \\
\text { Advanced } \\
\text { Search } \\
\text { Database - } \\
\text { CINAHL }\end{array}$ & 3,661 \\
\hline S121 & $\begin{array}{l}\text { S109 OR S110 OR S111 OR S112 OR S113 OR } \\
\text { S114 OR S115 OR S116 OR S117 OR S118 OR } \\
\text { S119 OR S120 }\end{array}$ & $\begin{array}{l}\text { Search modes - } \\
\text { Boolean/Phrase }\end{array}$ & $\begin{array}{l}\text { Interface - } \\
\text { EBSCOhost } \\
\text { Research } \\
\text { Databases } \\
\text { Search } \\
\text { Screen - } \\
\text { Advanced }\end{array}$ & 483,412 \\
\hline
\end{tabular}




\begin{tabular}{|c|c|c|c|c|}
\hline & & & $\begin{array}{l}\text { Search } \\
\text { Database - } \\
\text { CINAHL }\end{array}$ & \\
\hline S120 & $\begin{array}{l}\text { TI ( (singl* blind*) or (doubl* blind*) or } \\
\text { (tripl* blind*) or (trebl* blind* ) or (trebl* } \\
\text { mask*) or (tripl* mask*) or (doubl* mask*) } \\
\text { or (singl* mask*)) OR AB ( (singl* blind*) or } \\
\text { (doubl* blind*) or (tripl* blind*) or (trebl* } \\
\text { blind* ) or (trebl* mask*) or (tripl* mask*) } \\
\text { or (doubl* mask*) or (singl* mask*)) }\end{array}$ & $\begin{array}{l}\text { Search modes - } \\
\text { Boolean/Phrase }\end{array}$ & $\begin{array}{l}\text { Interface - } \\
\text { EBSCOhost } \\
\text { Research } \\
\text { Databases } \\
\text { Search } \\
\text { Screen - } \\
\text { Advanced } \\
\text { Search } \\
\text { Database - } \\
\text { CINAHL }\end{array}$ & 37,849 \\
\hline S119 & $\begin{array}{l}\text { TI Randomi?ed control* trial* OR AB } \\
\text { Randomi?ed control* trial* }\end{array}$ & $\begin{array}{l}\text { Search modes - } \\
\text { Boolean/Phrase }\end{array}$ & $\begin{array}{l}\text { Interface - } \\
\text { EBSCOhost } \\
\text { Research } \\
\text { Databases } \\
\text { Search } \\
\text { Screen - } \\
\text { Advanced } \\
\text { Search } \\
\text { Database - } \\
\text { CINAHL }\end{array}$ & 92,652 \\
\hline S118 & TI placebo* OR AB placebo* & $\begin{array}{l}\text { Search modes - } \\
\text { Boolean/Phrase }\end{array}$ & $\begin{array}{l}\text { Interface - } \\
\text { EBSCOhost } \\
\text { Research } \\
\text { Databases } \\
\text { Search } \\
\text { Screen - } \\
\text { Advanced } \\
\text { Search } \\
\text { Database - } \\
\text { CINAHL }\end{array}$ & 48,148 \\
\hline S117 & (MH "Random Assignment") & $\begin{array}{l}\text { Search modes - } \\
\text { Boolean/Phrase }\end{array}$ & $\begin{array}{l}\text { Interface - } \\
\text { EBSCOhost } \\
\text { Research } \\
\text { Databases } \\
\text { Search } \\
\text { Screen - } \\
\text { Advanced } \\
\text { Search } \\
\text { Database - } \\
\text { CINAHL }\end{array}$ & 51,988 \\
\hline S116 & (MH "Placebos") & $\begin{array}{l}\text { Search modes - } \\
\text { Boolean/Phrase }\end{array}$ & $\begin{array}{l}\text { Interface - } \\
\text { EBSCOhost } \\
\text { Research } \\
\text { Databases } \\
\text { Search } \\
\text { Screen - }\end{array}$ & 10,962 \\
\hline
\end{tabular}




\begin{tabular}{|c|c|c|c|c|}
\hline & & & $\begin{array}{l}\text { Advanced } \\
\text { Search } \\
\text { Database - } \\
\text { CINAHL }\end{array}$ & \\
\hline S115 & (MH "Quantitative Studies") & $\begin{array}{l}\text { Search modes - } \\
\text { Boolean/Phrase }\end{array}$ & $\begin{array}{l}\text { Interface - } \\
\text { EBSCOhost } \\
\text { Research } \\
\text { Databases } \\
\text { Search } \\
\text { Screen - } \\
\text { Advanced } \\
\text { Search } \\
\text { Database - } \\
\text { CINAHL }\end{array}$ & 21,254 \\
\hline S114 & TI allocat* random* OR AB allocat* random* & $\begin{array}{l}\text { Search modes - } \\
\text { Boolean/Phrase }\end{array}$ & $\begin{array}{l}\text { Interface - } \\
\text { EBSCOhost } \\
\text { Research } \\
\text { Databases } \\
\text { Search } \\
\text { Screen - } \\
\text { Advanced } \\
\text { Search } \\
\text { Database - } \\
\text { CINAHL }\end{array}$ & 9,469 \\
\hline S113 & $\begin{array}{l}\text { TI ( focus group* or qualitative or } \\
\text { ethnograph* or fieldwork or "field work" or } \\
\text { "key informant" ) OR AB ( focus group* or } \\
\text { qualitative or ethnograph* or fieldwork or } \\
\text { "field work" or "key informant" ) }\end{array}$ & $\begin{array}{l}\text { Search modes - } \\
\text { Boolean/Phrase }\end{array}$ & $\begin{array}{l}\text { Interface - } \\
\text { EBSCOhost } \\
\text { Research } \\
\text { Databases } \\
\text { Search } \\
\text { Screen - } \\
\text { Advanced } \\
\text { Search } \\
\text { Database - } \\
\text { CINAHL }\end{array}$ & 117,680 \\
\hline S112 & $\begin{array}{l}\text { TI ( ("semi-structured" or semistructured or } \\
\text { unstructured or informal or "in-depth" or } \\
\text { indepth or "face-to-face" or structured or } \\
\text { guide) n3 (interview* or discussion* or } \\
\text { questionnaire*) ) OR AB ( ("semi-structured" } \\
\text { or semistructured or unstructured or } \\
\text { informal or "in-depth" or indepth or "face- } \\
\text { to-face" or structured or guide) n3 } \\
\text { (interview* or discussion* or } \\
\text { questionnaire*) ) }\end{array}$ & $\begin{array}{l}\text { Search modes - } \\
\text { Boolean/Phrase }\end{array}$ & $\begin{array}{l}\text { Interface - } \\
\text { EBSCOhost } \\
\text { Research } \\
\text { Databases } \\
\text { Search } \\
\text { Screen - } \\
\text { Advanced } \\
\text { Search } \\
\text { Database - } \\
\text { CINAHL }\end{array}$ & 63,091 \\
\hline S111 & (MH "Ethnographic Research") & $\begin{array}{l}\text { Search modes - } \\
\text { Boolean/Phrase }\end{array}$ & \begin{tabular}{|l} 
Interface - \\
EBSCOhost \\
Research \\
Databases \\
Search
\end{tabular} & 6,974 \\
\hline
\end{tabular}




\begin{tabular}{|c|c|c|c|c|}
\hline & & & $\begin{array}{l}\text { Screen - } \\
\text { Advanced } \\
\text { Search } \\
\text { Database - } \\
\text { CINAHL }\end{array}$ & \\
\hline S110 & (MH "Qualitative Studies+") & $\begin{array}{l}\text { Search modes - } \\
\text { Boolean/Phrase }\end{array}$ & \begin{tabular}{|l} 
Interface - \\
EBSCOhost \\
Research \\
Databases \\
Search \\
Screen - \\
Advanced \\
Search \\
Database - \\
CINAHL
\end{tabular} & 121,879 \\
\hline S109 & $\begin{array}{l}\text { (MH "Interviews+") OR (MH "Focus Groups") } \\
\text { OR (MH "Narratives") }\end{array}$ & $\begin{array}{l}\text { Search modes - } \\
\text { Boolean/Phrase }\end{array}$ & \begin{tabular}{|l} 
Interface - \\
EBSCOhost \\
Research \\
Databases \\
Search \\
Screen - \\
Advanced \\
Search \\
Database - \\
CINAHL
\end{tabular} & 218,258 \\
\hline S108 & $\begin{array}{l}\text { S91 OR S92 OR S93 OR S94 OR S95 OR S96 } \\
\text { OR S97 OR S98 OR S99 OR S100 OR S101 OR } \\
\text { S102 OR S103 OR S104 OR S105 OR S106 OR } \\
\text { S107 }\end{array}$ & $\begin{array}{l}\text { Search modes - } \\
\text { Boolean/Phrase }\end{array}$ & \begin{tabular}{|l} 
Interface - \\
EBSCOhost \\
Research \\
Databases \\
Search \\
Screen - \\
Advanced \\
Search \\
Database - \\
CINAHL
\end{tabular} & $1,238,077$ \\
\hline S107 & TI technolog* OR AB technolog* & $\begin{array}{l}\text { Search modes - } \\
\text { Boolean/Phrase }\end{array}$ & \begin{tabular}{|l} 
Interface - \\
EBSCOhost \\
Research \\
Databases \\
Search \\
Screen - \\
Advanced \\
Search \\
Database - \\
CINAHL
\end{tabular} & 95,007 \\
\hline S106 & TI intervention* OR AB intervention* & $\begin{array}{l}\text { Search modes - } \\
\text { Boolean/Phrase }\end{array}$ & $\begin{array}{l}\text { Interface - } \\
\text { EBSCOhost } \\
\text { Research } \\
\text { Databases }\end{array}$ & 333,657 \\
\hline
\end{tabular}




\begin{tabular}{|c|c|c|c|c|}
\hline & & & $\begin{array}{l}\text { Search } \\
\text { Screen - } \\
\text { Advanced } \\
\text { Search } \\
\text { Database - } \\
\text { CINAHL }\end{array}$ & \\
\hline S105 & TI function* OR AB function* & $\begin{array}{l}\text { Search modes - } \\
\text { Boolean/Phrase }\end{array}$ & \begin{tabular}{|l} 
Interface - \\
EBSCOhost \\
Research \\
Databases \\
Search \\
Screen - \\
Advanced \\
Search \\
Database - \\
CINAHL
\end{tabular} & 342,044 \\
\hline S104 & TI movement* OR AB movement* & $\begin{array}{l}\text { Search modes - } \\
\text { Boolean/Phrase }\end{array}$ & \begin{tabular}{|l} 
Interface - \\
EBSCOhost \\
Research \\
Databases \\
Search \\
Screen - \\
Advanced \\
Search \\
Database - \\
CINAHL
\end{tabular} & 48,337 \\
\hline S103 & TI balance* OR AB balance* & $\begin{array}{l}\text { Search modes - } \\
\text { Boolean/Phrase }\end{array}$ & \begin{tabular}{|l} 
Interface - \\
EBSCOhost \\
Research \\
Databases \\
Search \\
Screen - \\
Advanced \\
Search \\
Database - \\
CINAHL
\end{tabular} & 47,136 \\
\hline S102 & $\begin{array}{l}\text { TI "physical therap*" OR AB "physical } \\
\text { therap*" }\end{array}$ & $\begin{array}{l}\text { Search modes - } \\
\text { Boolean/Phrase }\end{array}$ & \begin{tabular}{|l} 
Interface - \\
EBSCOhost \\
Research \\
Databases \\
Search \\
Screen - \\
Advanced \\
Search \\
Database - \\
CINAHL
\end{tabular} & 16,808 \\
\hline S101 & TI physio* OR AB physio* & $\begin{array}{l}\text { Search modes - } \\
\text { Boolean/Phrase }\end{array}$ & $\begin{array}{l}\text { Interface - } \\
\text { EBSCOhost } \\
\text { Research }\end{array}$ & 74,627 \\
\hline
\end{tabular}




\begin{tabular}{|c|c|c|c|c|}
\hline & & & $\begin{array}{l}\text { Databases } \\
\text { Search } \\
\text { Screen - } \\
\text { Advanced } \\
\text { Search } \\
\text { Database - } \\
\text { CINAHL }\end{array}$ & \\
\hline S100 & (MH "Physical Therapy+") & $\begin{array}{l}\text { Search modes - } \\
\text { Boolean/Phrase }\end{array}$ & $\begin{array}{l}\text { Interface - } \\
\text { EBSCOhost } \\
\text { Research } \\
\text { Databases } \\
\text { Search } \\
\text { Screen - } \\
\text { Advanced } \\
\text { Search } \\
\text { Database - } \\
\text { CINAHL }\end{array}$ & 119,639 \\
\hline S99 & TI mobilit* OR AB mobilit* & $\begin{array}{l}\text { Search modes - } \\
\text { Boolean/Phrase }\end{array}$ & $\begin{array}{l}\text { Interface - } \\
\text { EBSCOhost } \\
\text { Research } \\
\text { Databases } \\
\text { Search } \\
\text { Screen - } \\
\text { Advanced } \\
\text { Search } \\
\text { Database - } \\
\text { CINAHL }\end{array}$ & 21,198 \\
\hline S98 & TI activit* OR AB activit* & $\begin{array}{l}\text { Search modes - } \\
\text { Boolean/Phrase }\end{array}$ & $\begin{array}{l}\text { Interface - } \\
\text { EBSCOhost } \\
\text { Research } \\
\text { Databases } \\
\text { Search } \\
\text { Screen - } \\
\text { Advanced } \\
\text { Search } \\
\text { Database - } \\
\text { CINAHL }\end{array}$ & 260,293 \\
\hline S97 & $\begin{array}{l}\text { TI physical* n2 activ* OR AB physical* n2 } \\
\text { activ* }^{*}\end{array}$ & $\begin{array}{l}\text { Search modes - } \\
\text { Boolean/Phrase }\end{array}$ & $\begin{array}{l}\text { Interface - } \\
\text { EBSCOhost } \\
\text { Research } \\
\text { Databases } \\
\text { Search } \\
\text { Screen - } \\
\text { Advanced } \\
\text { Search } \\
\text { Database - } \\
\text { CINAHL }\end{array}$ & 49,526 \\
\hline S96 & TI exercise* OR AB exercise* & $\begin{array}{l}\text { Search modes - } \\
\text { Boolean/Phrase }\end{array}$ & $\begin{array}{l}\text { Interface - } \\
\text { EBSCOhost }\end{array}$ & 93,509 \\
\hline
\end{tabular}




\begin{tabular}{|c|c|c|c|c|}
\hline & & & \begin{tabular}{|l} 
Research \\
Databases \\
Search \\
Screen - \\
Advanced \\
Search \\
Database - \\
CINAHL
\end{tabular} & \\
\hline s95 & TI rehabilit* OR AB rehabilit* & $\begin{array}{l}\text { Search modes - } \\
\text { Boolean/Phrase }\end{array}$ & \begin{tabular}{|l} 
Interface - \\
EBSCOhost \\
Research \\
Databases \\
Search \\
Screen - \\
Advanced \\
Search \\
Database - \\
CINAHL
\end{tabular} & 74,956 \\
\hline S94 & (MH "Joint Mobilization") & $\begin{array}{l}\text { Search modes - } \\
\text { Boolean/Phrase }\end{array}$ & \begin{tabular}{|l} 
Interface - \\
EBSCOhost \\
Research \\
Databases \\
Search \\
Screen - \\
Advanced \\
Search \\
Database - \\
CINAHL \\
\end{tabular} & 768 \\
\hline s93 & (MH "Physical Activity") & $\begin{array}{l}\text { Search modes - } \\
\text { Boolean/Phrase }\end{array}$ & \begin{tabular}{|l} 
Interface - \\
EBSCOhost \\
Research \\
Databases \\
Search \\
Screen - \\
Advanced \\
Search \\
Database - \\
CINAHL
\end{tabular} & 32,177 \\
\hline s92 & (MH "Exercise+") & $\begin{array}{l}\text { Search modes - } \\
\text { Boolean/Phrase }\end{array}$ & \begin{tabular}{|l} 
Interface - \\
EBSCOhost \\
Research \\
Databases \\
Search \\
Screen - \\
Advanced \\
Search \\
Database - \\
CINAHL
\end{tabular} & 93,339 \\
\hline
\end{tabular}




\begin{tabular}{|c|c|c|c|c|}
\hline S91 & (MH "Rehabilitation+") & $\begin{array}{l}\text { Search modes - } \\
\text { Boolean/Phrase }\end{array}$ & $\begin{array}{l}\text { Interface - } \\
\text { EBSCOhost } \\
\text { Research } \\
\text { Databases } \\
\text { Search } \\
\text { Screen - } \\
\text { Advanced } \\
\text { Search } \\
\text { Database - } \\
\text { CINAHL }\end{array}$ & 241,272 \\
\hline S90 & $\begin{array}{l}\text { S63 OR S64 OR S65 OR S66 OR S67 OR S68 } \\
\text { OR S69 OR S70 OR S71 OR S72 OR S73 OR } \\
\text { S74 OR S75 OR S76 OR S77 OR S78 OR S79 } \\
\text { OR S80 OR S81 OR S82 OR S83 OR S84 OR } \\
\text { S85 OR S86 OR S87 OR S88 OR S89 }\end{array}$ & $\begin{array}{l}\text { Search modes - } \\
\text { Boolean/Phrase }\end{array}$ & $\begin{array}{l}\text { Interface - } \\
\text { EBSCOhost } \\
\text { Research } \\
\text { Databases } \\
\text { Search } \\
\text { Screen - } \\
\text { Advanced } \\
\text { Search } \\
\text { Database - } \\
\text { CINAHL }\end{array}$ & $2,177,370$ \\
\hline S89 & $\begin{array}{l}\text { TI ( bone* n3 (break* or broken) ) OR AB ( } \\
\text { bone* n3 (break* or broken) ) }\end{array}$ & $\begin{array}{l}\text { Search modes - } \\
\text { Boolean/Phrase }\end{array}$ & $\begin{array}{l}\text { Interface - } \\
\text { EBSCOhost } \\
\text { Research } \\
\text { Databases } \\
\text { Search } \\
\text { Screen - } \\
\text { Advanced } \\
\text { Search } \\
\text { Database - } \\
\text { CINAHL }\end{array}$ & 288 \\
\hline S88 & TI fracture* OR AB fracture* & $\begin{array}{l}\text { Search modes - } \\
\text { Boolean/Phrase }\end{array}$ & $\begin{array}{l}\text { Interface - } \\
\text { EBSCOhost } \\
\text { Research } \\
\text { Databases } \\
\text { Search } \\
\text { Screen - } \\
\text { Advanced } \\
\text { Search } \\
\text { Database - } \\
\text { CINAHL }\end{array}$ & 55,781 \\
\hline S87 & TI neurological* OR AB neurological* & $\begin{array}{l}\text { Search modes - } \\
\text { Boolean/Phrase }\end{array}$ & $\begin{array}{l}\text { Interface - } \\
\text { EBSCOhost } \\
\text { Research } \\
\text { Databases } \\
\text { Search } \\
\text { Screen - } \\
\text { Advanced } \\
\text { Search } \\
\end{array}$ & 31,620 \\
\hline
\end{tabular}




\begin{tabular}{|c|c|c|c|c|}
\hline & & & $\begin{array}{l}\text { Database - } \\
\text { CINAHL }\end{array}$ & \\
\hline S86 & TI diabet* OR AB diabet* & $\begin{array}{l}\text { Search modes - } \\
\text { Boolean/Phrase }\end{array}$ & $\begin{array}{l}\text { Interface - } \\
\text { EBSCOhost } \\
\text { Research } \\
\text { Databases } \\
\text { Search } \\
\text { Screen - } \\
\text { Advanced } \\
\text { Search } \\
\text { Database - } \\
\text { CINAHL }\end{array}$ & 154,177 \\
\hline S85 & $\begin{array}{l}\text { TI ( cancer* or metasta* or tumor* or } \\
\text { tumour* or carcinom* or malignan* or } \\
\text { neoplasm* ) OR AB ( cancer* or metasta* or } \\
\text { tumor* or tumour* or carcinom* or } \\
\text { malignan* or neoplasm*) }\end{array}$ & $\begin{array}{l}\text { Search modes - } \\
\text { Boolean/Phrase }\end{array}$ & $\begin{array}{l}\text { Interface - } \\
\text { EBSCOhost } \\
\text { Research } \\
\text { Databases } \\
\text { Search } \\
\text { Screen - } \\
\text { Advanced } \\
\text { Search } \\
\text { Database - } \\
\text { CINAHL }\end{array}$ & 438,844 \\
\hline S84 & TI parkinson* OR AB parkinson* & $\begin{array}{l}\text { Search modes - } \\
\text { Boolean/Phrase }\end{array}$ & $\begin{array}{l}\text { Interface - } \\
\text { EBSCOhost } \\
\text { Research } \\
\text { Databases } \\
\text { Search } \\
\text { Screen - } \\
\text { Advanced } \\
\text { Search } \\
\text { Database - } \\
\text { CINAHL }\end{array}$ & 21,020 \\
\hline S83 & $\begin{array}{l}\text { TI "cerebrovascular accident*" OR AB } \\
\text { "cerebrovascular accident*" }\end{array}$ & $\begin{array}{l}\text { Search modes - } \\
\text { Boolean/Phrase }\end{array}$ & $\begin{array}{l}\text { Interface - } \\
\text { EBSCOhost } \\
\text { Research } \\
\text { Databases } \\
\text { Search } \\
\text { Screen - } \\
\text { Advanced } \\
\text { Search } \\
\text { Database - } \\
\text { CINAHL }\end{array}$ & 1,353 \\
\hline S82 & TI stroke OR AB stroke & $\begin{array}{l}\text { Search modes - } \\
\text { Boolean/Phrase }\end{array}$ & $\begin{array}{l}\text { Interface - } \\
\text { EBSCOhost } \\
\text { Research } \\
\text { Databases } \\
\text { Search } \\
\text { Screen - } \\
\text { Advanced }\end{array}$ & 72,953 \\
\hline
\end{tabular}




\begin{tabular}{|c|c|c|c|c|}
\hline & & & \begin{tabular}{|l} 
Search \\
Database - \\
CINAHL
\end{tabular} & \\
\hline S81 & $\begin{array}{l}\text { TI ( fall or falls or falling or fell ) OR AB ( fall } \\
\text { or falls or falling or fell ) }\end{array}$ & $\begin{array}{l}\text { Search modes - } \\
\text { Boolean/Phrase }\end{array}$ & $\begin{array}{l}\text { Interface - } \\
\text { EBSCOhost } \\
\text { Research } \\
\text { Databases } \\
\text { Search } \\
\text { Screen - } \\
\text { Advanced } \\
\text { Search } \\
\text { Database - } \\
\text { CINAHL }\end{array}$ & 43,394 \\
\hline S80 & TI balance* OR AB balance* & $\begin{array}{l}\text { Search modes - } \\
\text { Boolean/Phrase }\end{array}$ & $\begin{array}{l}\text { Interface - } \\
\text { EBSCOhost } \\
\text { Research } \\
\text { Databases } \\
\text { Search } \\
\text { Screen - } \\
\text { Advanced } \\
\text { Search } \\
\text { Database - } \\
\text { CINAHL }\end{array}$ & 47,136 \\
\hline S79 & $\begin{array}{l}\text { TI "physical disease*" OR AB "physical } \\
\text { disease*" }\end{array}$ & $\begin{array}{l}\text { Search modes - } \\
\text { Boolean/Phrase }\end{array}$ & $\begin{array}{l}\text { Interface - } \\
\text { EBSCOhost } \\
\text { Research } \\
\text { Databases } \\
\text { Search } \\
\text { Screen - } \\
\text { Advanced } \\
\text { Search } \\
\text { Database - } \\
\text { CINAHL }\end{array}$ & 261 \\
\hline S78 & TI rheumat* OR AB rheumat* & $\begin{array}{l}\text { Search modes - } \\
\text { Boolean/Phrase }\end{array}$ & $\begin{array}{l}\text { Interface - } \\
\text { EBSCOhost } \\
\text { Research } \\
\text { Databases } \\
\text { Search } \\
\text { Screen - } \\
\text { Advanced } \\
\text { Search } \\
\text { Database - } \\
\text { CINAHL }\end{array}$ & 28,167 \\
\hline S77 & $\begin{array}{l}\text { TI "musculo-skeletal*" OR AB "musculo- } \\
\text { skeletal*" }\end{array}$ & $\begin{array}{l}\text { Search modes - } \\
\text { Boolean/Phrase }\end{array}$ & \begin{tabular}{|l} 
Interface - \\
EBSCOhost \\
Research \\
Databases \\
Search \\
Screen -
\end{tabular} & 252 \\
\hline
\end{tabular}




\begin{tabular}{|c|c|c|c|c|}
\hline & & & \begin{tabular}{|l} 
Advanced \\
Search \\
Database - \\
CINAHL
\end{tabular} & \\
\hline S76 & TI musculoskeletal* OR AB musculoskeletal* & $\begin{array}{l}\text { Search modes - } \\
\text { Boolean/Phrase }\end{array}$ & \begin{tabular}{|l} 
Interface - \\
EBSCOhost \\
Research \\
Databases \\
Search \\
Screen - \\
Advanced \\
Search \\
Database - \\
CINAHL
\end{tabular} & 19,406 \\
\hline S75 & TI longterm* OR AB longterm* & $\begin{array}{l}\text { Search modes - } \\
\text { Boolean/Phrase }\end{array}$ & \begin{tabular}{|l} 
Interface - \\
EBSCOhost \\
Research \\
Databases \\
Search \\
Screen - \\
Advanced \\
Search \\
Database - \\
CINAHL
\end{tabular} & 1,142 \\
\hline S74 & TI "long term*" OR AB "long term*" & $\begin{array}{l}\text { Search modes - } \\
\text { Boolean/Phrase }\end{array}$ & \begin{tabular}{|l} 
Interface - \\
EBSCOhost \\
Research \\
Databases \\
Search \\
Screen - \\
Advanced \\
Search \\
Database - \\
CINAHL
\end{tabular} & 137,633 \\
\hline S73 & TI prolong* OR AB prolong* & $\begin{array}{l}\text { Search modes - } \\
\text { Boolean/Phrase }\end{array}$ & \begin{tabular}{|l} 
Interface - \\
EBSCOhost \\
Research \\
Databases \\
Search \\
Screen - \\
Advanced \\
Search \\
Database - \\
CINAHL
\end{tabular} & 40,418 \\
\hline$S 72$ & TI chronic* OR AB chronic* & $\begin{array}{l}\text { Search modes - } \\
\text { Boolean/Phrase }\end{array}$ & $\begin{array}{l}\text { Interface - } \\
\text { EBSCOhost } \\
\text { Research } \\
\text { Databases } \\
\text { Search }\end{array}$ & 199,208 \\
\hline
\end{tabular}




\begin{tabular}{|c|c|c|c|c|}
\hline & & & $\begin{array}{l}\text { Screen - } \\
\text { Advanced } \\
\text { Search } \\
\text { Database - } \\
\text { CINAHL }\end{array}$ & \\
\hline S71 & (MH "Fractures+") & $\begin{array}{l}\text { Search modes - } \\
\text { Boolean/Phrase }\end{array}$ & $\begin{array}{l}\text { Interface - } \\
\text { EBSCOhost } \\
\text { Research } \\
\text { Databases } \\
\text { Search } \\
\text { Screen - } \\
\text { Advanced } \\
\text { Search } \\
\text { Database - } \\
\text { CINAHL }\end{array}$ & 47,499 \\
\hline S70 & (MH "Accidental Falls") & $\begin{array}{l}\text { Search modes - } \\
\text { Boolean/Phrase }\end{array}$ & $\begin{array}{l}\text { Interface - } \\
\text { EBSCOhost } \\
\text { Research } \\
\text { Databases } \\
\text { Search } \\
\text { Screen - } \\
\text { Advanced } \\
\text { Search } \\
\text { Database - } \\
\text { CINAHL }\end{array}$ & 18,599 \\
\hline S69 & (MH "Endocrine Diseases+") & $\begin{array}{l}\text { Search modes - } \\
\text { Boolean/Phrase }\end{array}$ & $\begin{array}{l}\text { Interface - } \\
\text { EBSCOhost } \\
\text { Research } \\
\text { Databases } \\
\text { Search } \\
\text { Screen - } \\
\text { Advanced } \\
\text { Search } \\
\text { Database - } \\
\text { CINAHL }\end{array}$ & 263,090 \\
\hline S68 & (MH "Cardiovascular Diseases+") & $\begin{array}{l}\text { Search modes - } \\
\text { Boolean/Phrase }\end{array}$ & $\begin{array}{l}\text { Interface - } \\
\text { EBSCOhost } \\
\text { Research } \\
\text { Databases } \\
\text { Search } \\
\text { Screen - } \\
\text { Advanced } \\
\text { Search } \\
\text { Database - } \\
\text { CINAHL }\end{array}$ & 473,431 \\
\hline S67 & (MH "Nervous System Diseases+") & $\begin{array}{l}\text { Search modes - } \\
\text { Boolean/Phrase }\end{array}$ & $\begin{array}{l}\text { Interface - } \\
\text { EBSCOhost } \\
\text { Research } \\
\text { Databases }\end{array}$ & 615,504 \\
\hline
\end{tabular}




\begin{tabular}{|c|c|c|c|c|}
\hline & & & $\begin{array}{l}\text { Search } \\
\text { Screen - } \\
\text { Advanced } \\
\text { Search } \\
\text { Database - } \\
\text { CINAHL }\end{array}$ & \\
\hline S66 & (MH "Respiratory Tract Diseases+") & $\begin{array}{l}\text { Search modes - } \\
\text { Boolean/Phrase }\end{array}$ & \begin{tabular}{|l} 
Interface - \\
EBSCOhost \\
Research \\
Databases \\
Search \\
Screen - \\
Advanced \\
Search \\
Database - \\
CINAHL \\
\end{tabular} & 235,349 \\
\hline S65 & (MH "Musculoskeletal Diseases+") & $\begin{array}{l}\text { Search modes - } \\
\text { Boolean/Phrase }\end{array}$ & \begin{tabular}{|l} 
Interface - \\
EBSCOhost \\
Research \\
Databases \\
Search \\
Screen - \\
Advanced \\
Search \\
Database - \\
CINAHL \\
\end{tabular} & 218,708 \\
\hline S64 & (MH "Neoplasms+") & $\begin{array}{l}\text { Search modes - } \\
\text { Boolean/Phrase }\end{array}$ & \begin{tabular}{|l} 
Interface - \\
EBSCOhost \\
Research \\
Databases \\
Search \\
Screen - \\
Advanced \\
Search \\
Database - \\
CINAHL
\end{tabular} & 441,955 \\
\hline S63 & (MH "Chronic Disease") & $\begin{array}{l}\text { Search modes - } \\
\text { Boolean/Phrase }\end{array}$ & \begin{tabular}{|l} 
Interface - \\
EBSCOhost \\
Research \\
Databases \\
Search \\
Screen - \\
Advanced \\
Search \\
Database - \\
CINAHL
\end{tabular} & 53,110 \\
\hline S62 & $\begin{array}{l}\text { S20 OR S21 OR S22 OR S23 OR S24 OR S25 } \\
\text { OR S26 OR S27 OR S28 OR S29 OR S30 OR } \\
\text { S31 OR S32 OR S33 OR S34 OR S35 OR S36 }\end{array}$ & $\begin{array}{l}\text { Search modes - } \\
\text { Boolean/Phrase }\end{array}$ & $\begin{array}{l}\text { Interface - } \\
\text { EBSCOhost } \\
\text { Research }\end{array}$ & 362,628 \\
\hline
\end{tabular}




\begin{tabular}{|c|c|c|c|c|}
\hline & $\begin{array}{l}\text { OR S37 OR S38 OR S39 OR S40 OR S41 OR } \\
\text { S42 OR S43 OR S44 OR S45 OR S46 OR S47 } \\
\text { OR S48 OR S49 OR S50 OR S51 OR S52 OR } \\
\text { S53 OR S54 OR S55 OR S56 OR S57 OR S58 } \\
\text { OR S59 OR S60 OR S61 }\end{array}$ & & $\begin{array}{l}\text { Databases } \\
\text { Search } \\
\text { Screen - } \\
\text { Advanced } \\
\text { Search } \\
\text { Database - } \\
\text { CINAHL }\end{array}$ & \\
\hline S61 & TI cdrom* OR AB cdrom* & $\begin{array}{l}\text { Search modes - } \\
\text { Boolean/Phrase }\end{array}$ & $\begin{array}{l}\text { Interface - } \\
\text { EBSCOhost } \\
\text { Research } \\
\text { Databases } \\
\text { Search } \\
\text { Screen - } \\
\text { Advanced } \\
\text { Search } \\
\text { Database - } \\
\text { CINAHL }\end{array}$ & 39 \\
\hline S60 & TI "CD rom*" OR AB "CD rom*" & $\begin{array}{l}\text { Search modes - } \\
\text { Boolean/Phrase }\end{array}$ & \begin{tabular}{|l} 
Interface - \\
EBSCOhost \\
Research \\
Databases \\
Search \\
Screen - \\
Advanced \\
Search \\
Database - \\
CINAHL
\end{tabular} & 1,085 \\
\hline S59 & TI skype* OR AB skype* & $\begin{array}{l}\text { Search modes - } \\
\text { Boolean/Phrase }\end{array}$ & \begin{tabular}{|l} 
Interface - \\
EBSCOhost \\
Research \\
Databases \\
Search \\
Screen - \\
Advanced \\
Search \\
Database - \\
CINAHL
\end{tabular} & 237 \\
\hline S58 & $\begin{array}{l}\text { TI ( app* n3 (smartphone* or smart-phone } \\
\text { or mobile* or phone*) ) OR AB ( app* n3 } \\
\text { (smartphone* or smart-phone or mobile* or } \\
\text { phone*)) }\end{array}$ & $\begin{array}{l}\text { Search modes - } \\
\text { Boolean/Phrase }\end{array}$ & $\begin{array}{l}\text { Interface - } \\
\text { EBSCOhost } \\
\text { Research } \\
\text { Databases } \\
\text { Search } \\
\text { Screen - } \\
\text { Advanced } \\
\text { Search } \\
\text { Database - } \\
\text { CINAHL }\end{array}$ & 4,413 \\
\hline S57 & TI ipad* OR AB ipad* & $\begin{array}{l}\text { Search modes - } \\
\text { Boolean/Phrase }\end{array}$ & \begin{tabular}{|l|} 
Interface - \\
EBSCOhost
\end{tabular} & 832 \\
\hline
\end{tabular}




\begin{tabular}{|c|c|c|c|c|}
\hline & & & \begin{tabular}{|l} 
Research \\
Databases \\
Search \\
Screen - \\
Advanced \\
Search \\
Database - \\
CINAHL
\end{tabular} & \\
\hline S56 & TI android* OR AB android* & $\begin{array}{l}\text { Search modes - } \\
\text { Boolean/Phrase }\end{array}$ & \begin{tabular}{|l} 
Interface - \\
EBSCOhost \\
Research \\
Databases \\
Search \\
Screen - \\
Advanced \\
Search \\
Database - \\
CINAHL
\end{tabular} & 595 \\
\hline S55 & $\begin{array}{l}\text { TI ( windows n3 (mobile* or phone*) ) OR } \\
A B(\text { windows n3 (mobile* or phone*)) }\end{array}$ & $\begin{array}{l}\text { Search modes - } \\
\text { Boolean/Phrase }\end{array}$ & \begin{tabular}{|l} 
Interface - \\
EBSCOhost \\
Research \\
Databases \\
Search \\
Screen - \\
Advanced \\
Search \\
Database - \\
CINAHL \\
\end{tabular} & 28 \\
\hline S54 & TI symbian OR AB symbian & Search modes - & \begin{tabular}{|l} 
Interface - \\
EBSCOhost \\
Research \\
Databases \\
Search \\
Screen - \\
Advanced \\
Search \\
Database - \\
CINAHL
\end{tabular} & 3 \\
\hline S53 & TI blackberry OR AB blackberry & $\begin{array}{l}\text { Search modes - } \\
\text { Boolean/Phrase }\end{array}$ & \begin{tabular}{|l} 
Interface - \\
EBSCOhost \\
Research \\
Databases \\
Search \\
Screen - \\
Advanced \\
Search \\
Database - \\
CINAHL
\end{tabular} & 132 \\
\hline
\end{tabular}




\begin{tabular}{|c|c|c|c|c|}
\hline S52 & TI nokia OR AB nokia & $\begin{array}{l}\text { Search modes - } \\
\text { Boolean/Phrase }\end{array}$ & $\begin{array}{l}\text { Interface - } \\
\text { EBSCOhost } \\
\text { Research } \\
\text { Databases } \\
\text { Search } \\
\text { Screen - } \\
\text { Advanced } \\
\text { Search } \\
\text { Database - } \\
\text { CINAHL }\end{array}$ & 40 \\
\hline S51 & TI "voice messag*" OR AB "voice messag*" & $\begin{array}{l}\text { Search modes - } \\
\text { Boolean/Phrase }\end{array}$ & $\begin{array}{l}\text { Interface - } \\
\text { EBSCOhost } \\
\text { Research } \\
\text { Databases } \\
\text { Search } \\
\text { Screen - } \\
\text { Advanced } \\
\text { Search } \\
\text { Database - } \\
\text { CINAHL }\end{array}$ & 48 \\
\hline S50 & TI iphone* OR AB iphone* & $\begin{array}{l}\text { Search modes - } \\
\text { Boolean/Phrase }\end{array}$ & $\begin{array}{l}\text { Interface - } \\
\text { EBSCOhost } \\
\text { Research } \\
\text { Databases } \\
\text { Search } \\
\text { Screen - } \\
\text { Advanced } \\
\text { Search } \\
\text { Database - } \\
\text { CINAHL }\end{array}$ & 512 \\
\hline S49 & $\begin{array}{l}\mathrm{TI} \text { ( txt or pxt or mms or sms) OR AB (txt or } \\
\text { pxt or mms or sms) }\end{array}$ & $\begin{array}{l}\text { Search modes - } \\
\text { Boolean/Phrase }\end{array}$ & $\begin{array}{l}\text { Interface - } \\
\text { EBSCOhost } \\
\text { Research } \\
\text { Databases } \\
\text { Search } \\
\text { Screen - } \\
\text { Advanced } \\
\text { Search } \\
\text { Database - } \\
\text { CINAHL }\end{array}$ & 1,447 \\
\hline S48 & TI "text messag*" OR AB "text messag*" & $\begin{array}{l}\text { Search modes - } \\
\text { Boolean/Phrase }\end{array}$ & \begin{tabular}{|l} 
Interface - \\
EBSCOhost \\
Research \\
Databases \\
Search \\
Screen - \\
Advanced \\
Search \\
\end{tabular} & 1,942 \\
\hline
\end{tabular}




\begin{tabular}{|c|c|c|c|c|}
\hline & & & $\begin{array}{l}\text { Database - } \\
\text { CINAHL }\end{array}$ & \\
\hline S47 & TI "smart phone*" OR AB "smart phone*" & $\begin{array}{l}\text { Search modes - } \\
\text { Boolean/Phrase }\end{array}$ & $\begin{array}{l}\text { Interface - } \\
\text { EBSCOhost } \\
\text { Research } \\
\text { Databases } \\
\text { Search } \\
\text { Screen - } \\
\text { Advanced } \\
\text { Search } \\
\text { Database - } \\
\text { CINAHL }\end{array}$ & 395 \\
\hline S46 & TI smartphone* OR AB smartphone* & $\begin{array}{l}\text { Search modes - } \\
\text { Boolean/Phrase }\end{array}$ & $\begin{array}{l}\text { Interface - } \\
\text { EBSCOhost } \\
\text { Research } \\
\text { Databases } \\
\text { Search } \\
\text { Screen - } \\
\text { Advanced } \\
\text { Search } \\
\text { Database - } \\
\text { CINAHL }\end{array}$ & 3,500 \\
\hline S45 & $\begin{array}{l}\text { TI ( cell n2 (phone* or telephon*) ) OR AB ( } \\
\text { cell n2 (phone* or telephon*)) }\end{array}$ & $\begin{array}{l}\text { Search modes - } \\
\text { Boolean/Phrase }\end{array}$ & $\begin{array}{l}\text { Interface - } \\
\text { EBSCOhost } \\
\text { Research } \\
\text { Databases } \\
\text { Search } \\
\text { Screen - } \\
\text { Advanced } \\
\text { Search } \\
\text { Database - } \\
\text { CINAHL }\end{array}$ & 1,192 \\
\hline S44 & $\begin{array}{l}\text { TI ( mobile n2 (phone* or telephon*) ) OR } \\
\text { AB ( mobile n2 (phone* or telephon*)) }\end{array}$ & $\begin{array}{l}\text { Search modes - } \\
\text { Boolean/Phrase }\end{array}$ & $\begin{array}{l}\text { Interface - } \\
\text { EBSCOhost } \\
\text { Research } \\
\text { Databases } \\
\text { Search } \\
\text { Screen - } \\
\text { Advanced } \\
\text { Search } \\
\text { Database - } \\
\text { CINAHL }\end{array}$ & 2,636 \\
\hline S43 & $\begin{array}{l}\mathrm{TI} \text { ( telemedicine or tele-medicine ) OR AB ( } \\
\text { telemedicine or tele-medicine ) }\end{array}$ & $\begin{array}{l}\text { Search modes - } \\
\text { Boolean/Phrase }\end{array}$ & $\begin{array}{l}\text { Interface - } \\
\text { EBSCOhost } \\
\text { Research } \\
\text { Databases } \\
\text { Search } \\
\text { Screen - } \\
\text { Advanced }\end{array}$ & 3,911 \\
\hline
\end{tabular}




\begin{tabular}{|c|c|c|c|c|}
\hline & & & $\begin{array}{l}\text { Search } \\
\text { Database - } \\
\text { CINAHL }\end{array}$ & \\
\hline S42 & $\begin{array}{l}\text { TI ( telerehabilitation or tele-rehabilitation } \\
\text { or "tele rehabilitation" ) OR AB ( } \\
\text { telerehabilitation or tele-rehabilitation or } \\
\text { "tele rehabilitation" ) }\end{array}$ & $\begin{array}{l}\text { Search modes - } \\
\text { Boolean/Phrase }\end{array}$ & $\begin{array}{l}\text { Interface - } \\
\text { EBSCOhost } \\
\text { Research } \\
\text { Databases } \\
\text { Search } \\
\text { Screen - } \\
\text { Advanced } \\
\text { Search } \\
\text { Database - } \\
\text { CINAHL }\end{array}$ & 367 \\
\hline S41 & $\begin{array}{l}\text { TI ( email* or e-mail* or "e mail*" ) OR AB ( } \\
\text { email* or e-mail* or "e mail*") }\end{array}$ & $\begin{array}{l}\text { Search modes - } \\
\text { Boolean/Phrase }\end{array}$ & $\begin{array}{l}\text { Interface - } \\
\text { EBSCOhost } \\
\text { Research } \\
\text { Databases } \\
\text { Search } \\
\text { Screen - } \\
\text { Advanced } \\
\text { Search } \\
\text { Database - } \\
\text { CINAHL }\end{array}$ & 7,915 \\
\hline S40 & (MH "Electronic Mail") & $\begin{array}{l}\text { Search modes - } \\
\text { SmartText Searching }\end{array}$ & $\begin{array}{l}\text { Interface - } \\
\text { EBSCOhost } \\
\text { Research } \\
\text { Databases } \\
\text { Search } \\
\text { Screen - } \\
\text { Advanced } \\
\text { Search } \\
\text { Database - } \\
\text { CINAHL }\end{array}$ & 991 \\
\hline S39 & (MH "Electronic Mail") & $\begin{array}{l}\text { Search modes - } \\
\text { Boolean/Phrase }\end{array}$ & $\begin{array}{l}\text { Interface - } \\
\text { EBSCOhost } \\
\text { Research } \\
\text { Databases } \\
\text { Search } \\
\text { Screen - } \\
\text { Advanced } \\
\text { Search } \\
\text { Database - } \\
\text { CINAHL }\end{array}$ & 0 \\
\hline S38 & $\begin{array}{l}\text { TI ( "social media" or twitter or tweet* or } \\
\text { facebook or blog* or microblog*) OR AB ( } \\
\text { "social media" or twitter or tweet* or } \\
\text { facebook or blog* or microblog*) }\end{array}$ & $\begin{array}{l}\text { Search modes - } \\
\text { Boolean/Phrase }\end{array}$ & $\begin{array}{l}\text { Interface - } \\
\text { EBSCOhost } \\
\text { Research } \\
\text { Databases } \\
\text { Search } \\
\text { Screen - }\end{array}$ & 12,266 \\
\hline
\end{tabular}




\begin{tabular}{|c|c|c|c|c|}
\hline & & & $\begin{array}{l}\text { Advanced } \\
\text { Search } \\
\text { Database - } \\
\text { CINAHL }\end{array}$ & \\
\hline S37 & TI digital* OR AB digital* & $\begin{array}{l}\text { Search modes - } \\
\text { Boolean/Phrase }\end{array}$ & $\begin{array}{l}\text { Interface - } \\
\text { EBSCOhost } \\
\text { Research } \\
\text { Databases } \\
\text { Search } \\
\text { Screen - } \\
\text { Advanced } \\
\text { Search } \\
\text { Database - } \\
\text { CINAHL }\end{array}$ & 26,504 \\
\hline S36 & TI virtual* OR AB virtual* & $\begin{array}{l}\text { Search modes - } \\
\text { Boolean/Phrase }\end{array}$ & $\begin{array}{l}\text { Interface - } \\
\text { EBSCOhost } \\
\text { Research } \\
\text { Databases } \\
\text { Search } \\
\text { Screen - } \\
\text { Advanced } \\
\text { Search } \\
\text { Database - } \\
\text { CINAHL }\end{array}$ & 17,174 \\
\hline S35 & $\begin{array}{l}\text { TI ( "technology based" or technologybased } \\
\text { or technology-based) OR AB ( "technology } \\
\text { based" or technologybased or technology- } \\
\text { based ) }\end{array}$ & $\begin{array}{l}\text { Search modes - } \\
\text { Boolean/Phrase }\end{array}$ & $\begin{array}{l}\text { Interface - } \\
\text { EBSCOhost } \\
\text { Research } \\
\text { Databases } \\
\text { Search } \\
\text { Screen - } \\
\text { Advanced } \\
\text { Search } \\
\text { Database - } \\
\text { CINAHL }\end{array}$ & 880 \\
\hline S34 & TI internet* OR AB internet* & $\begin{array}{l}\text { Search modes - } \\
\text { Boolean/Phrase }\end{array}$ & $\begin{array}{l}\text { Interface - } \\
\text { EBSCOhost } \\
\text { Research } \\
\text { Databases } \\
\text { Search } \\
\text { Screen - } \\
\text { Advanced } \\
\text { Search } \\
\text { Database - } \\
\text { CINAHL }\end{array}$ & 24,751 \\
\hline S33 & TI online OR AB online & $\begin{array}{l}\text { Search modes - } \\
\text { Boolean/Phrase }\end{array}$ & $\begin{array}{l}\text { Interface - } \\
\text { EBSCOhost } \\
\text { Research } \\
\text { Databases } \\
\text { Search }\end{array}$ & 47,302 \\
\hline
\end{tabular}




\begin{tabular}{|c|c|c|c|c|}
\hline & & & $\begin{array}{l}\text { Screen - } \\
\text { Advanced } \\
\text { Search } \\
\text { Database - } \\
\text { CINAHL } \\
\end{array}$ & \\
\hline S32 & TI web* OR AB web* & $\begin{array}{l}\text { Search modes - } \\
\text { Boolean/Phrase }\end{array}$ & \begin{tabular}{|l} 
Interface - \\
EBSCOhost \\
Research \\
Databases \\
Search \\
Screen - \\
Advanced \\
Search \\
Database - \\
CINAHL
\end{tabular} & 53,766 \\
\hline S31 & TI compute* OR AB compute* & $\begin{array}{l}\text { Search modes - } \\
\text { Boolean/Phrase }\end{array}$ & $\begin{array}{l}\text { Interface - } \\
\text { EBSCOhost } \\
\text { Research } \\
\text { Databases } \\
\text { Search } \\
\text { Screen - } \\
\text { Advanced } \\
\text { Search } \\
\text { Database - } \\
\text { CINAHL }\end{array}$ & 109,582 \\
\hline S30 & TI mhealth* OR AB mhealth* & $\begin{array}{l}\text { Search modes - } \\
\text { Boolean/Phrase }\end{array}$ & \begin{tabular}{|l} 
Interface - \\
EBSCOhost \\
Research \\
Databases \\
Search \\
Screen - \\
Advanced \\
Search \\
Database - \\
CINAHL
\end{tabular} & 999 \\
\hline S29 & TI "mobile health*" OR AB "mobile health*" & $\begin{array}{l}\text { Search modes - } \\
\text { Boolean/Phrase }\end{array}$ & \begin{tabular}{|l} 
Interface - \\
EBSCOhost \\
Research \\
Databases \\
Search \\
Screen - \\
Advanced \\
Search \\
Database - \\
CINAHL
\end{tabular} & 1,108 \\
\hline S28 & TI "m-health*" OR AB "m-health*" & $\begin{array}{l}\text { Search modes - } \\
\text { Boolean/Phrase }\end{array}$ & \begin{tabular}{|l} 
Interface - \\
EBSCOhost \\
Research \\
Databases
\end{tabular} & 139 \\
\hline
\end{tabular}




\begin{tabular}{|c|c|c|c|c|}
\hline & & & $\begin{array}{l}\text { Search } \\
\text { Screen - } \\
\text { Advanced } \\
\text { Search } \\
\text { Database - } \\
\text { CINAHL }\end{array}$ & \\
\hline$S 27$ & TI ehealth* OR AB ehealth* & $\begin{array}{l}\text { Search modes - } \\
\text { Boolean/Phrase }\end{array}$ & $\begin{array}{l}\text { Interface - } \\
\text { EBSCOhost } \\
\text { Research } \\
\text { Databases } \\
\text { Search } \\
\text { Screen - } \\
\text { Advanced } \\
\text { Search } \\
\text { Database - } \\
\text { CINAHL }\end{array}$ & 1,564 \\
\hline$S 26$ & TI "e-health*" OR AB "e-health*" & $\begin{array}{l}\text { Search modes - } \\
\text { Boolean/Phrase }\end{array}$ & $\begin{array}{l}\text { Interface - } \\
\text { EBSCOhost } \\
\text { Research } \\
\text { Databases } \\
\text { Search } \\
\text { Screen - } \\
\text { Advanced } \\
\text { Search } \\
\text { Database - } \\
\text { CINAHL } \\
\end{array}$ & 1,152 \\
\hline$S 25$ & (MH "Mobile Applications") & $\begin{array}{l}\text { Search modes - } \\
\text { Boolean/Phrase }\end{array}$ & \begin{tabular}{|l} 
Interface - \\
EBSCOhost \\
Research \\
Databases \\
Search \\
Screen - \\
Advanced \\
Search \\
Database - \\
CINAHL \\
\end{tabular} & 4,410 \\
\hline$S 24$ & (MH "Mobile Applications") & $\begin{array}{l}\text { Search modes - } \\
\text { Boolean/Phrase }\end{array}$ & \begin{tabular}{|l} 
Interface - \\
EBSCOhost \\
Research \\
Databases \\
Search \\
Screen - \\
Advanced \\
Search \\
Database - \\
CINAHL \\
\end{tabular} & 4,410 \\
\hline$S 23$ & (MH "Cellular Phone+") & $\begin{array}{l}\text { Search modes - } \\
\text { Boolean/Phrase }\end{array}$ & $\begin{array}{l}\text { Interface - } \\
\text { EBSCOhost } \\
\text { Research }\end{array}$ & 4,733 \\
\hline
\end{tabular}




\begin{tabular}{|c|c|c|c|c|}
\hline & & & $\begin{array}{l}\text { Databases } \\
\text { Search } \\
\text { Screen - } \\
\text { Advanced } \\
\text { Search } \\
\text { Database - } \\
\text { CINAHL }\end{array}$ & \\
\hline S22 & (MH "Multimedia") & $\begin{array}{l}\text { Search modes - } \\
\text { Boolean/Phrase }\end{array}$ & $\begin{array}{l}\text { Interface - } \\
\text { EBSCOhost } \\
\text { Research } \\
\text { Databases } \\
\text { Search } \\
\text { Screen - } \\
\text { Advanced } \\
\text { Search } \\
\text { Database - } \\
\text { CINAHL }\end{array}$ & 1,852 \\
\hline S21 & (MH "Telehealth+") & $\begin{array}{l}\text { Search modes - } \\
\text { Boolean/Phrase }\end{array}$ & $\begin{array}{l}\text { Interface - } \\
\text { EBSCOhost } \\
\text { Research } \\
\text { Databases } \\
\text { Search } \\
\text { Screen - } \\
\text { Advanced } \\
\text { Search } \\
\text { Database - } \\
\text { CINAHL }\end{array}$ & 17,746 \\
\hline S20 & (MH "Internet+") & $\begin{array}{l}\text { Search modes - } \\
\text { Boolean/Phrase }\end{array}$ & $\begin{array}{l}\text { Interface - } \\
\text { EBSCOhost } \\
\text { Research } \\
\text { Databases } \\
\text { Search } \\
\text { Screen - } \\
\text { Advanced } \\
\text { Search } \\
\text { Database - } \\
\text { CINAHL }\end{array}$ & 121,755 \\
\hline S19 & $\begin{array}{l}\text { S1 OR S2 OR S3 OR S4 OR S5 OR S6 OR S7 OR } \\
\text { S8 OR S9 OR S10 OR S11 OR S12 OR S13 OR } \\
\text { S14 OR S15 OR S16 OR S17 OR S18 }\end{array}$ & $\begin{array}{l}\text { Search modes - } \\
\text { Boolean/Phrase }\end{array}$ & $\begin{array}{l}\text { Interface - } \\
\text { EBSCOhost } \\
\text { Research } \\
\text { Databases } \\
\text { Search } \\
\text { Screen - } \\
\text { Advanced } \\
\text { Search } \\
\text { Database - } \\
\text { CINAHL }\end{array}$ & $1,141,739$ \\
\hline S18 & $\begin{array}{l}\text { TI "older population*" OR AB "older } \\
\text { population*" }\end{array}$ & $\begin{array}{l}\text { Search modes - } \\
\text { Boolean/Phrase }\end{array}$ & $\begin{array}{l}\text { Interface - } \\
\text { EBSCOhost }\end{array}$ & 2,454 \\
\hline
\end{tabular}




\begin{tabular}{|c|c|c|c|c|}
\hline & & & $\begin{array}{l}\text { Research } \\
\text { Databases } \\
\text { Search } \\
\text { Screen - } \\
\text { Advanced } \\
\text { Search } \\
\text { Database - } \\
\text { CINAHL }\end{array}$ & \\
\hline S17 & TI veteran* OR AB veteran* & $\begin{array}{l}\text { Search modes - } \\
\text { Boolean/Phrase }\end{array}$ & $\begin{array}{l}\text { Interface - } \\
\text { EBSCOhost } \\
\text { Research } \\
\text { Databases } \\
\text { Search } \\
\text { Screen - } \\
\text { Advanced } \\
\text { Search } \\
\text { Database - } \\
\text { CINAHL }\end{array}$ & 17,068 \\
\hline S16 & TI frail* OR AB frail* & $\begin{array}{l}\text { Search modes - } \\
\text { Boolean/Phrase }\end{array}$ & $\begin{array}{l}\text { Interface - } \\
\text { EBSCOhost } \\
\text { Research } \\
\text { Databases } \\
\text { Search } \\
\text { Screen - } \\
\text { Advanced } \\
\text { Search } \\
\text { Database - } \\
\text { CINAHL }\end{array}$ & 9,144 \\
\hline S15 & TI pensioner* OR AB pensioner* & $\begin{array}{l}\text { Search modes - } \\
\text { Boolean/Phrase }\end{array}$ & $\begin{array}{l}\text { Interface - } \\
\text { EBSCOhost } \\
\text { Research } \\
\text { Databases } \\
\text { Search } \\
\text { Screen - } \\
\text { Advanced } \\
\text { Search } \\
\text { Database - } \\
\text { CINAHL }\end{array}$ & 190 \\
\hline S14 & TI geriatric* OR AB geriatric* & $\begin{array}{l}\text { Search modes - } \\
\text { Boolean/Phrase }\end{array}$ & $\begin{array}{l}\text { Interface - } \\
\text { EBSCOhost } \\
\text { Research } \\
\text { Databases } \\
\text { Search } \\
\text { Screen - } \\
\text { Advanced } \\
\text { Search } \\
\text { Database - } \\
\text { CINAHL }\end{array}$ & 18,974 \\
\hline
\end{tabular}




\begin{tabular}{|c|c|c|c|c|}
\hline S13 & TI "aging adult*" OR AB "aging adult*" & $\begin{array}{l}\text { Search modes - } \\
\text { Boolean/Phrase }\end{array}$ & $\begin{array}{l}\text { Interface - } \\
\text { EBSCOhost } \\
\text { Research } \\
\text { Databases } \\
\text { Search } \\
\text { Screen - } \\
\text { Advanced } \\
\text { Search } \\
\text { Database - } \\
\text { CINAHL }\end{array}$ & 317 \\
\hline S12 & TI "ageing adult*" OR AB "ageing adult*" & $\begin{array}{l}\text { Search modes - } \\
\text { Boolean/Phrase }\end{array}$ & \begin{tabular}{|l} 
Interface - \\
EBSCOhost \\
Research \\
Databases \\
Search \\
Screen - \\
Advanced \\
Search \\
Database - \\
CINAHL
\end{tabular} & 26 \\
\hline S11 & TI "aging person*" OR AB "aging person*" & $\begin{array}{l}\text { Search modes - } \\
\text { Boolean/Phrase }\end{array}$ & $\begin{array}{l}\text { Interface - } \\
\text { EBSCOhost } \\
\text { Research } \\
\text { Databases } \\
\text { Search } \\
\text { Screen - } \\
\text { Advanced } \\
\text { Search } \\
\text { Database - } \\
\text { CINAHL }\end{array}$ & 60 \\
\hline S10 & TI "ageing person*" OR AB "ageing person*" & $\begin{array}{l}\text { Search modes - } \\
\text { Boolean/Phrase }\end{array}$ & \begin{tabular}{|l} 
Interface - \\
EBSCOhost \\
Research \\
Databases \\
Search \\
Screen - \\
Advanced \\
Search \\
Database - \\
CINAHL
\end{tabular} & 19 \\
\hline S9 & TI "old* people" OR AB "old* people" & $\begin{array}{l}\text { Search modes - } \\
\text { Boolean/Phrase }\end{array}$ & \begin{tabular}{|l} 
Interface - \\
EBSCOhost \\
Research \\
Databases \\
Search \\
Screen - \\
Advanced \\
Search \\
\end{tabular} & 19,580 \\
\hline
\end{tabular}




\begin{tabular}{|c|c|c|c|c|}
\hline & & & $\begin{array}{l}\text { Database - } \\
\text { CINAHL }\end{array}$ & \\
\hline S8 & TI "old* adult*" OR AB "old* adult*" & $\begin{array}{l}\text { Search modes - } \\
\text { Boolean/Phrase }\end{array}$ & $\begin{array}{l}\text { Interface - } \\
\text { EBSCOhost } \\
\text { Research } \\
\text { Databases } \\
\text { Search } \\
\text { Screen - } \\
\text { Advanced } \\
\text { Search } \\
\text { Database - } \\
\text { CINAHL }\end{array}$ & 44,437 \\
\hline S7 & TI "old* person*" OR AB "old* person*" & $\begin{array}{l}\text { Search modes - } \\
\text { Boolean/Phrase }\end{array}$ & $\begin{array}{l}\text { Interface - } \\
\text { EBSCOhost } \\
\text { Research } \\
\text { Databases } \\
\text { Search } \\
\text { Screen - } \\
\text { Advanced } \\
\text { Search } \\
\text { Database - } \\
\text { CINAHL }\end{array}$ & 6,413 \\
\hline S6 & TI "old* age*" OR AB "old* age*" & $\begin{array}{l}\text { Search modes - } \\
\text { Boolean/Phrase }\end{array}$ & $\begin{array}{l}\text { Interface - } \\
\text { EBSCOhost } \\
\text { Research } \\
\text { Databases } \\
\text { Search } \\
\text { Screen - } \\
\text { Advanced } \\
\text { Search } \\
\text { Database - } \\
\text { CINAHL }\end{array}$ & 17,983 \\
\hline S5 & TI senior* OR AB senior* & $\begin{array}{l}\text { Search modes - } \\
\text { Boolean/Phrase }\end{array}$ & $\begin{array}{l}\text { Interface - } \\
\text { EBSCOhost } \\
\text { Research } \\
\text { Databases } \\
\text { Search } \\
\text { Screen - } \\
\text { Advanced } \\
\text { Search } \\
\text { Database - } \\
\text { CINAHL }\end{array}$ & 19,649 \\
\hline S4 & TI elder* OR AB elder* & $\begin{array}{l}\text { Search modes - } \\
\text { Boolean/Phrase }\end{array}$ & $\begin{array}{l}\text { Interface - } \\
\text { EBSCOhost } \\
\text { Research } \\
\text { Databases } \\
\text { Search } \\
\text { Screen - } \\
\text { Advanced }\end{array}$ & 82,198 \\
\hline
\end{tabular}




\begin{tabular}{|c|c|c|c|c|}
\hline & & & $\begin{array}{l}\text { Search } \\
\text { Database - } \\
\text { CINAHL }\end{array}$ & \\
\hline S3 & (MH "Veterans+") & $\begin{array}{l}\text { Search modes - } \\
\text { Boolean/Phrase }\end{array}$ & $\begin{array}{l}\text { Interface - } \\
\text { EBSCOhost } \\
\text { Research } \\
\text { Databases } \\
\text { Search } \\
\text { Screen - } \\
\text { Advanced } \\
\text { Search } \\
\text { Database - } \\
\text { CINAHL }\end{array}$ & 13,422 \\
\hline S2 & (MH "Aging+") & $\begin{array}{l}\text { Search modes - } \\
\text { Boolean/Phrase }\end{array}$ & $\begin{array}{l}\text { Interface - } \\
\text { EBSCOhost } \\
\text { Research } \\
\text { Databases } \\
\text { Search } \\
\text { Screen - } \\
\text { Advanced } \\
\text { Search } \\
\text { Database - } \\
\text { CINAHL }\end{array}$ & 43,966 \\
\hline S1 & (MH "Aged+") OR (MH "Middle Age") & $\begin{array}{l}\text { Search modes - } \\
\text { Boolean/Phrase }\end{array}$ & $\begin{array}{l}\text { Interface - } \\
\text { EBSCOhost } \\
\text { Research } \\
\text { Databases } \\
\text { Search } \\
\text { Screen - } \\
\text { Advanced } \\
\text { Search } \\
\text { Database - } \\
\text { CINAHL }\end{array}$ & $1,058,000$ \\
\hline
\end{tabular}

\begin{tabular}{|lll|}
\hline \multicolumn{2}{|l|}{ Cochrane Central Register of Controlled Trials } \\
\hline Issue 10 of 12, October 2018 \\
\hline ID & Search Hits & \\
\hline$\# 1$ & MeSH descriptor: [Aged] explode all trees & $\mathrm{n}$ \\
\hline$\# 2$ & MeSH descriptor: [Middle Aged] explode all trees & 1696 \\
\hline$\# 3$ & MeSH descriptor: [Aging] explode all trees & 1406 \\
\hline$\# 4$ & elder*.ti,ab. & 3503 \\
\hline$\# 5$ & senior*.ti,ab. & 0 \\
\hline$\# 6$ & "old* age*".ti,ab. & 0 \\
\hline$\# 7$ & "old* person*".ti,ab. & 5122 \\
\hline
\end{tabular}




\begin{tabular}{|c|c|c|}
\hline \#8 & "old* adult*".ti,ab. & 4277 \\
\hline \#9 & "old* people".ti,ab. & 4489 \\
\hline \#10 & "ageing person*".ti,ab. & 4258 \\
\hline \#11 & "aging person*".ti,ab. & 4258 \\
\hline \#12 & "ageing adult*".ti,ab. & 4269 \\
\hline$\# 13$ & "aging adult*".ti,ab. & 4269 \\
\hline \#14 & geriatric*.ti,ab. & 0 \\
\hline \#15 & pensioner*.ti,ab. & 0 \\
\hline \#16 & frail*.ti,ab. & 0 \\
\hline \#17 & MeSH descriptor: [Veterans] explode all trees & 802 \\
\hline \#18 & veteran*.ti,ab. & 0 \\
\hline \#19 & "older population*".ti,ab. & 4628 \\
\hline \multicolumn{3}{|c|}{$\begin{array}{l}\# 20 \# 1 \text { or } \# 2 \text { or \#3 or \#4 or \#5 or \#6 or \#7 or \#8 or \#9 or \#10 or \#11 or \#12 or \#13 or \#14 or \#15 } \\
\text { or \#16 or \#17 or \#18 or \#19 }\end{array}$} \\
\hline & 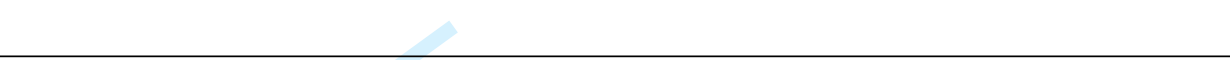 & 11701 \\
\hline \#21 & MeSH descriptor: [Internet] explode all trees & 3372 \\
\hline \#22 & MeSH descriptor: [Telemedicine] explode all trees & 1950 \\
\hline \#23 & MeSH descriptor: [Computers] explode all trees 1425 & \\
\hline \#24 & MeSH descriptor: [Multimedia] explode all trees 200 & \\
\hline \#25 & MeSH descriptor: [Cell Phone] explode all trees 1030 & \\
\hline \#26 & MeSH descriptor: [Mobile Applications] explode all trees & 324 \\
\hline \#27 & "e-health*".ti,ab. & 7049 \\
\hline \#28 & ehealth*.ti,ab. & 0 \\
\hline \#29 & "m-health*".ti,ab. & 6773 \\
\hline$\# 30$ & "mobile health*".ti,ab. & 4827 \\
\hline \#31 & mhealth*.ti,ab. & 0 \\
\hline \#32 & compute*.ti,ab. & 0 \\
\hline \#33 & web*.ti,ab. & 0 \\
\hline \#34 & online.ti,ab. & 2 \\
\hline \#35 & internet.ti,ab. & 7 \\
\hline \#36 & ("technology based" or technologybased or technology-based).ti,ab. & 4258 \\
\hline \#37 & virtual*.ti,ab. & 0 \\
\hline \#38 & digital*.ti,ab. & 0 \\
\hline \#39 & ("social media" or twitter or tweet* or facebook or blog* or microblog*).ti,ab. & 4260 \\
\hline$\# 40$ & MeSH descriptor: [Electronic Mail] explode all trees & 293 \\
\hline \#41 & (email* or e-mail* or "e mail*").ti,ab. & 4294 \\
\hline \#42 & (telerehabilitation or tele-rehabilitation or "tele rehabilitation").ti,ab. & 4258 \\
\hline \#43 & (telemedicine or tele-medicine).ti,ab. & 4259 \\
\hline \#44 & (mobile near/2 (phone* or telephon*)).ti,ab. & 4258 \\
\hline \#45 & (cell near/2 (phone* or telephon*)).ti,ab. & 4258 \\
\hline \#46 & smartphone*.ti,ab. & 0 \\
\hline \#47 & "smart phone*".ti,ab. & 4496 \\
\hline$\# 48$ & "text messag*".ti,ab. & 4274 \\
\hline \#49 & (txt or pxt or mms or sms).ti,ab. & 4258 \\
\hline
\end{tabular}




\begin{tabular}{|c|c|c|}
\hline \#50 & iphone*.ti,ab. & 0 \\
\hline \#51 & "voice messag*".ti,ab. & 4260 \\
\hline \#52 & nokia.ti,ab. & 7 \\
\hline \#53 & blackberry.ti,ab. & 1 \\
\hline \#54 & symbian.ti,ab. & 0 \\
\hline \#55 & (windows near/2 (mobile* or phone*)).ti,ab. & 4258 \\
\hline \#56 & android.ti,ab. & 8 \\
\hline \#57 & ipad*.ti,ab. & 0 \\
\hline \#58 & (app* near/3 (smartphone* OR smart-phone* OR mobile* OR phone*)).ti,ab. & 4258 \\
\hline \#59 & skype*.ti,ab. & 0 \\
\hline \#60 & "cd rom*".ti,ab. & 4491 \\
\hline \#61 & cdrom*.ti,ab. & 0 \\
\hline $\begin{array}{l}\# 62 \\
\# 34 \\
\# 48\end{array}$ & \multicolumn{2}{|c|}{$\begin{array}{l}\# 21 \text { or } \# 22 \text { or } \# 23 \text { or } \# 24 \text { or } \# 25 \text { or } \# 26 \text { or } \# 27 \text { or } \# 28 \text { or } \# 29 \text { or } \# 30 \text { or } \# 31 \text { or } \# 32 \text { or } \# 33 \text { or } \\
\# 35 \text { or } \# 36 \text { or } \# 37 \text { or } \# 38 \text { or } \# 39 \text { or } \# 40 \text { or } \# 41 \text { or } \# 42 \text { or } \# 43 \text { or } \# 44 \text { or } \# 45 \text { or } \# 46 \text { or } \# 47 \text { or } \\
\# 49 \text { or } \# 50 \text { or } \# 51 \text { or } \# 52 \text { or } \# 53 \text { or } \# 54 \text { or } \# 55 \text { or } \# 56 \text { or } \# 57 \text { or } \# 58 \text { or } \# 59 \text { or } \# 60 \text { or } \# 61 \\
15663\end{array}$} \\
\hline \#63 & MeSH descriptor: [Chronic Disease] explode all trees & 12335 \\
\hline \#64 & \multicolumn{2}{|l|}{ MeSH descriptor: [Neoplasms] explode all trees 67613} \\
\hline \#65 & MeSH descriptor: [Musculoskeletal Diseases] explode all trees & 34576 \\
\hline \#66 & MeSH descriptor: [Respiratory Tract Diseases] explode all trees & 52607 \\
\hline \#67 & MeSH descriptor: [Nervous System Diseases] explode all trees & 72091 \\
\hline \#68 & MeSH descriptor: [Cardiovascular Diseases] explode all trees & 94071 \\
\hline \#69 & MeSH descriptor: [Endocrine System Diseases] explode all trees & 35730 \\
\hline \#70 & MeSH descriptor: [Accidental Falls] explode all trees & 1283 \\
\hline$\# 71$ & MeSH descriptor: [Fractures, Bone] explode all trees & 5196 \\
\hline \#72 & chronic*.ti,ab. & 0 \\
\hline \#73 & prolong*.ti,ab. & 0 \\
\hline \#74 & "long term*".ti,ab. & 80028 \\
\hline \#75 & longterm*.ti,ab. & 0 \\
\hline \#76 & musculoskeletal*.ti,ab. & 0 \\
\hline \#77 & musculo-skeletal*.ti,ab. & 0 \\
\hline \#78 & rheumat*.ti,ab. & 0 \\
\hline \#79 & "physical disease*".ti,ab. & 4865 \\
\hline$\# 80$ & balance*.ti,ab. & 0 \\
\hline \#81 & (fall or falls or falling or fell).ti,ab. & 4275 \\
\hline$\# 82$ & stroke.ti,ab. & 11 \\
\hline \#83 & "cerebrovascular accident*".ti,ab. & 12172 \\
\hline \#84 & parkinson*.ti,ab. & 0 \\
\hline \#85 & (cancer* or metasta* or tumor* or tumour* or carcinom* or malignan* or neo & $\begin{array}{l}\text { lasm*).ti,ab. } \\
4276\end{array}$ \\
\hline \#86 & diabet*.ti,ab. & 0 \\
\hline \#87 & neurological*.ti,ab. & 0 \\
\hline$\# 88$ & fracture*.ti,ab. & 0 \\
\hline \#89 & (bone* near/3 (break* or broken)).ti,ab. & 4258 \\
\hline
\end{tabular}




\begin{tabular}{|llc|}
\hline$\# 90$ & $\# 63$ or $\# 64$ or $\# 65$ or \#66 or \#67 or \#68 or \#69 or \#70 or \#71 or \#72 or \#73 or \#74 or \#75 or \\
$\# 76$ or $\# 77$ or \#78 or \#79 or \#80 or \#81 or \#82 or \#83 or \#84 or \#85 or \#86 or \#87 or \#88 or \#89 & 367193 \\
\hline & & 30780 \\
\hline$\# 91$ & MeSH descriptor: [Rehabilitation] explode all trees & 20923 \\
\hline$\# 92$ & MeSH descriptor: [Exercise] explode all trees & 0 \\
\hline$\# 93$ & rehabilit*.ti,ab. & 0 \\
\hline$\# 94$ & exercise*.ti,ab. & 4258 \\
\hline$\# 95$ & (physical* near/2 activ*).ti,ab. & 0 \\
\hline$\# 96$ & activit*.ti,ab. & 0 \\
\hline$\# 97$ & mobilit*.ti,ab. & 117 \\
\hline$\# 98$ & MeSH descriptor: [Physical Therapy Specialty] explode all trees & 0 \\
\hline$\# 99$ & physio*.ti,ab. & 4294 \\
\hline$\# 100$ & "physical therap*".ti,ab. & 0 \\
\hline$\# 101$ & balance*.ti,ab. & 0 \\
\hline$\# 102$ & movement*.ti,ab. & 0 \\
\hline$\# 103$ & function*.ti,ab. & 0 \\
\hline$\# 104$ & intervention*.ti,ab. & 0 \\
\hline$\# 105$ & technolog*.ti,ab. & 49447 \\
\hline$\# 106$ & $\# 91$ or \#92 or \#93 or \#94 or \#95 or \#96 or \#97 or \#98 or \#99 or \#100 or \#101 or \#102 or \#103 \\
\hline or \#104 or \#105 & 4318 \\
\hline$\# 107$ & $\# 20$ and \#62 and \#90 and \#106 \\
\hline
\end{tabular}

\section{Search Strategies $(08 / 11 / 18)$}

PEDro https://search.pedro.org.au/advanced-search/continue-search

The Abstract \& Title field was searched for combinations for each of the following terms from two sets of concepts:

Elder*; senior*; older; aging; ageing; geriatric*; pensioner*; frail*; veteran*;

AND

Internet*; telehealth*; compute*; multimedia*; phone; e-health*; ehealth*; "mobile health"; mhealth*; mhealth*; web*; online*; technolog*; virtual*; digital*; "social media"; twitter; tweet; facebook; blog*; microblog*; email*; e-mail*; "e mail*"; telerehab*; "tele-rehab*"; "tele rehab*"; telemedicine; tele-medicine; "text messag*"; "cell telephon*"; smartphone*; "smart-phone*"; txt; pxt; mms; sms; iphone*; "voice messag*"; nokia; blackberry; Symbian; windows; android; ipad*; skype*; "cd rom*"; cdrom*.

For example: elder* AND internet*

Manually removing non-English-language references 


\section{Search Results}

\begin{tabular}{|l|l|}
\hline Ovid Medline (searched 06/11/18) & 16366 \\
\hline Ovid Embase (searched 06/11/18) & 15361 \\
\hline Ebsco CINAHL (searched 06/11/18) & 3623 \\
\hline Cochrane CENTRAL (searched 06/11/18) & 27 \\
\hline PEDro (searched 07/11/18) & 454 \\
\hline Total & 35831 \\
\hline Total after deduplication & 25961 \\
\hline
\end{tabular}

15

16 